\title{
On the Mechanism of the Selenolactonization Reaction with Selenenyl Halides
}

Scott E. Denmark and Michael G. Edwards

Department of Chemistry, University of Illinois Urbana-Champaign, Urbana, Illinois 61801

\section{SUPPORTING INFORMATION}

Table of Contents

Page

General Experimental

Literature Preparations

Experimental Procedures

Preparative Selenolactonization Reactions

VT NMR Experiments

References

NMR Spectra

$S 42$

\section{General Experimental}

All reactions were performed in oven-dried $\left(150{ }^{\circ} \mathrm{C}\right)$ or flame-dried glassware. All reaction temperatures correspond to internal temperatures measured by Teflon-coated thermocouples unless otherwise noted. Reaction solvents including dichloromethane (HPLC Grade), diethyl ether (BHT stabilizied HPLC Grade) and tetrahydrofuran (FHPLC Grade) were dried by percolation through two columns packed with neutral alumina under a positive pressure of argon. $N, N$-Dimethylformamide (ACS Grade) was dried sequentially over two batches of activated $4 \AA$ molecular sieves. Solvents for chromatography were: hexanes (ACS Grade), diethyl ether (ACS Grade), acetic acid (ACS Grade) and dichloromethane (technical grade, distilled from $\mathrm{CaCl}_{2}$ ). Column chromatography was performed using EM Science 230-400-mesh silica gel. Hexamethyldisilazane, tert-butyldimethylsilyl chloride (TBSCl), tert-butyldiphenylsilyl chloride (TBDPSCl), phenylacetaldehyde, triethylsilylchloride (TESCl), trimethylsilylchloride (TMSCl), and triisopropylsilylchloride (TIPSCl) were freshly distilled prior to use. 4Dimethylaminopyridine (DMAP) was recrystallized from ethyl acetate prior to use. Pyridine and triethylamine $\left(\mathrm{Et}_{3} \mathrm{~N}\right)$ were freshly distilled from $\mathrm{CaH}_{2}$ prior to use. 3-Butyn-1-ol, 2,6-di-tert- 
butyl-4-methylpyridine, bromine, chlorine, copper(I) iodide, dichlorobis(triphenylphosphine)palladium(II), $N$-(3-dimethylaminopropyl)- $N$ '-ethylcarbodiimide hydrochloride (EDC.HCl), 2,2dimethylpropan-1-ol (neopentyl alcohol), imidazole, malonic acid, 2-methyl-2-butene, saccharin, and sodium Chlorite were used without further purification. Sodium methoxyethoxyaluminium hydride (Red-Al) was titrated according to the method of Hoye et al. ${ }^{1}$

${ }^{1} \mathrm{H}$ NMR, ${ }^{13} \mathrm{C}$ NMR and ${ }^{19} \mathrm{~F}$ NMR were recorded on $500 \mathrm{MHz},{ }^{1} \mathrm{H} ; 470 \mathrm{MHz},{ }^{19} \mathrm{~F} ; 126$ $\mathrm{MHz},{ }^{13} \mathrm{C}$ spectrometers. Spectra were referenced to residual chloroform $\left(7.26 \mathrm{ppm},{ }^{1} \mathrm{H} ; 77.00\right.$ ppm, ${ }^{13} \mathrm{C}$ ). ${ }^{77} \mathrm{Se}$ NMR spectra were recorded on at $143 \mathrm{MHz}$ and are referenced to $\mathrm{Me}_{2} \mathrm{Se}$ as an external standard. Chemical shifts are reported in ppm, multiplicities are indicated by s (singlet), $\mathrm{d}$ (doublet), $\mathrm{t}$ (triplet), q (quartet), sep (septet), $\mathrm{m}$ (multiplet) and br (broad). Coupling constants, $J$, are reported in Hertz. ${ }^{1} \mathrm{H}$ and ${ }^{13} \mathrm{C}$ NMR assignments are corroborated by $2 \mathrm{D}$ experiments (HETCOR and COSY). Spectra are available on request from denmark@scs.uiuc.edu.Mass spectroscopy data (EI, CI, FAB) are reported in the form of $(\mathrm{m} / \mathrm{z})$. Infrared spectra (IR) were recorded in $\mathrm{NaCl}$ cells and peaks are reported in $\mathrm{cm}^{-1}$ with indicated relative intensities: $\mathrm{s}$ (strong, 67-100\%); m (medium, 34-66\%); w (weak, 0-33\%). React-IR experiments were performed on a React-IR 1000 machine with a 5/8-inch DiComp probe. Melting points (mp) were determined in sealed tubes and are corrected. Kugelrohr distillation temperatures reported are air bath temperatures (ABT). Analytical thin-layer chromatography was performed on Merck silica gel plates with QF-254 indicator. Visualization was accomplished with UV (254 $\mathrm{nm})$, and potassium permanganate $\left(\mathrm{KMnO}_{4}\right)$ or ceric ammonium molybdate (CAM) staining solutions.

\section{Literature Preparations}

Benzeneselenenyl bromide was prepared according to Reich et al. and was recrystallized from $\mathrm{CHCl}_{3} /$ hexane. ${ }^{2}$ Benzeneselenenyl chloride prepared following the procedure described by Schmid and Garratt ${ }^{3}$ was recrystallized from $\mathrm{CH}_{2} \mathrm{Cl}_{2}$ /hexane. 1,1,1-Triacetoxy-1,1-dihydro-1,2benziodoxol-3(1H)-one [DMP] was prepared by the procedure described by Boeckman and co workers. ${ }^{4}$ Triethylsilyl acetate was prepared according to the method of Bradley and Thomas. ${ }^{5}$ 


\subsection{Preparation of Carboxylic Acid 10 and its Ester Derivatives}

\section{Preparation of (E)-4-Phenyl-3-butenoic acid (10) ${ }^{6}$ [MGE-VII-34]}

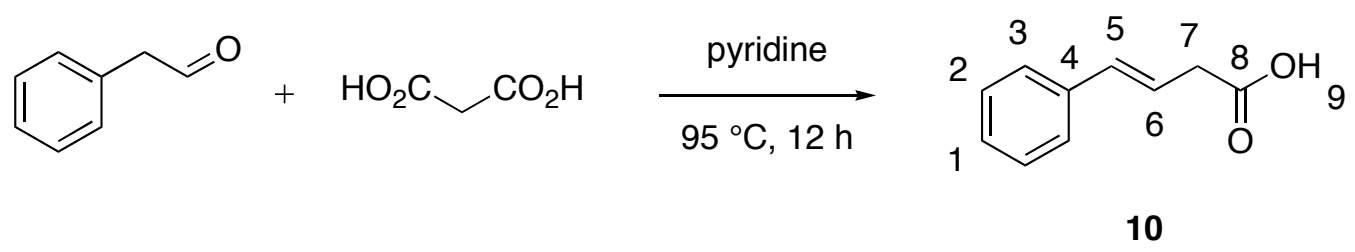

A one-neck, 100-mL round-bottom flask containing a magnetic stir bar was charged with freshly distilled phenylacetaldehdye (26.50 g, $220 \mathrm{mmol}, 1.05$ equiv), malonic acid (21.85g, 210 mmol, 1.0 equiv) and pyridine (17.45 g, $220 \mathrm{mmol}, 1.05$ equiv). A reflux condensor was fitted and the mixture stirred vigorously and placed in an oil-bath pre-heated to $95{ }^{\circ} \mathrm{C}$. The rapid formation of a yellow/orange homogeneous solution was accompanied by the evolution of gas and the mixture was heated overnight at $95{ }^{\circ} \mathrm{C}(12 \mathrm{~h})$ before the resultant orange solution was cooled to room temperature. The cooled mixture was transferred to a $500-\mathrm{mL}$ separatory funnel containing $\mathrm{Et}_{2} \mathrm{O}(200 \mathrm{~mL})$ and was extracted with $2 \mathrm{M}$ aqueous $\mathrm{NaOH}$ solution $(3 \times 200 \mathrm{~mL})$. The organic layer was discarded and the aqueous extract transferred to a 1-L Erlenmeyer flask containing a stir bar. Dropwise addition of concentrated sulfuric acid $(15 \mathrm{ml})$ acidified the solution to $\mathrm{pH}$ 1-2 (litmus paper) [CARE: mixture becomes warm] resulting in the separation of an organic layer. The mixture was returned to a separatory funnel and was extracted with $\mathrm{Et}_{2} \mathrm{O}$ (3 $\times 100 \mathrm{~mL})$. The combined organic extracts were washed with water $(100 \mathrm{~mL})$ and saturated brine $(200 \mathrm{~mL})$, dried $\left(\mathrm{MgSO}_{4}\right)$, filtered and concentrated in vacuo to afford $23.50 \mathrm{~g}$ of a crude yellow powder. The crude material was distilled under reduced pressure $\left(0.04 \mathrm{~mm} \mathrm{Hg}, 180{ }^{\circ} \mathrm{C}\right.$ oil-bath $)$ through a short-path apparatus containing a $10 \mathrm{~cm}$ Vigreux column to afford $15.60 \mathrm{~g}$ of a colorless liquid that solidified as a dense cream solid upon cooling. NMR analysis showed this material to be a 10:1 mixture of $\beta, \gamma / \alpha, \beta$ isomers and $50: 1 E / Z$ stereiosomers. Final purification was achieved by recrystallization twice from boiling heptane $(2 \mathrm{~mL} / \mathrm{g}$ solid). [CAUTION: On no account should the hot solute be cooled below room temperature since this results in crystallization of the minor $\alpha, \beta$-isomer]. The crystallized product was washed with ice-cold pentane $(10 \mathrm{~mL})$ and dried under high vacuum $(0.05 \mathrm{~mm} \mathrm{Hg})$ to afford $11.60 \mathrm{~g}(33 \%)$ of 10 as 
colorless needles.

Data for $(E)-\mathbf{1 0}$ :

bp: $\quad 126-128^{\circ} \mathrm{C}(0.04 \mathrm{mmHg})$

mp: $\quad 85-87^{\circ} \mathrm{C}$ (heptane)

${ }^{1} \mathrm{H}$ NMR: $\quad\left(500 \mathrm{MHz}, \mathrm{CDCl}_{3}\right)$

11.99 (br. s, $1 \mathrm{H}, \mathrm{OH}(9)$ ), 7.40 (d, $J=7.7,2 \mathrm{H}, \mathrm{CH}(3)), 7.34$ (t, $J=7.6,2 \mathrm{H}$, $\mathrm{HC}(2)), 7.26(\mathrm{t}, J=7.3,1 \mathrm{H}, \mathrm{HC}(1)), 6.54$ (d, $J=15.8,1 \mathrm{H}, \mathrm{HC}(5)), 6.31$ (dt, $J=$ 15.8, 7.2, $1 \mathrm{H}, \mathrm{HC}(6)), 3.32\left(\mathrm{dd}, 2 \mathrm{H}, J=7.1,1.3,2 \mathrm{H}, \mathrm{H}_{2} \mathrm{C}(7)\right)$

${ }^{13} \mathrm{C} \mathrm{NMR}: \quad\left(126 \mathrm{MHz}, \mathrm{CDCl}_{3}\right)$

$178.5(\mathrm{C}(8)), 136.5(\mathrm{C}(4)), 133.9(\mathrm{C}(5)), 128.5(\mathrm{C}(2)), 127.6(\mathrm{C}(1)), 126.2(\mathrm{C}(3))$, 120.6 (C(6)), 37.9 (C(7))

IR: $\quad\left(\mathrm{CH}_{2} \mathrm{Cl}_{2}\right)$

3073 (br. m), 3059 (m), 2952 (m), 2884 (m), 1953 (w), 1882 (w), 1818 (w), 1704

(s), $1598(\mathrm{w}), 1576(\mathrm{w}), 1493$ (w), 1448 (m), 1417 (s), 1403 (s), 1298 (m), 1278

(m), 1265 (m), 1224 (m), 1177 (m), 1067 (w), 977 (s), 918 (m), 813 (w), 745 (s), $693(\mathrm{~s}), 667(\mathrm{~m})$

MS: $\quad(\mathrm{EI}, 70 \mathrm{eV})$

$162\left(\left(\mathrm{M}^{+}, 57\right), 118(11), 117(100), 115(32), 117(65), 91\right.$ (16)

\section{Preparation of $(E)$-Trimethylsilyl 4-Phenyl-3-butenoate (15b) [MGE-VII-25]}<smiles>O=C(O)C/C=C/c1ccccc1</smiles>

10

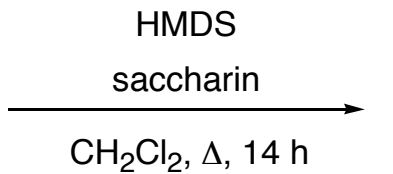

$\mathrm{CH}_{2} \mathrm{Cl}_{2}, \Delta, 14 \mathrm{~h}$

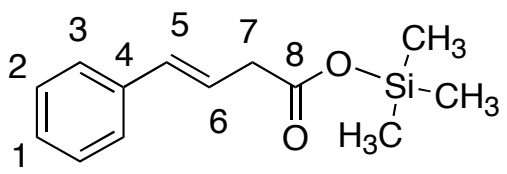

$15 b$

A 250-mL, 1-neck, round-bottom flask containing a magnetic stir bar was charged with 4phenyl-3-butenoic acid 10 (3.00 g, $18.50 \mathrm{mmol}, 1.0$ equiv) and saccharin (34 mg, $0.185 \mathrm{mmol}$, 0.01 equiv). A reflux condenser mounted with a T-adaptor connected to a nitrogen-inlet adaptor and an exit oil-bubbler was fitted to the flask. The apparatus was placed under a positive flow of nitrogen and $\mathrm{CH}_{2} \mathrm{Cl}_{2}(70 \mathrm{~mL})$ added via syringe. The colorless solution thus obtained was stirred vigorously and hexamethyldisilazane (4.478 g, $27.75 \mathrm{mmol}, 1.5$ equiv, $5.90 \mathrm{~mL})$ added dropwise 
resulting in the immediate formation of a colorless suspension. The mixture was placed in a 50 ${ }^{\circ} \mathrm{C}$ oil-bath and heated to reflux overnight $(14 \mathrm{~h})$. The colorless solution thus obtained was cooled to room temperature and the volatiles carefully removed in vacuo by rotary evaporation with the exclusion of moisture. The flask was then backfilled with nitrogen and connected to a pre-arranged short-path distillation apparatus. Distillation under reduced pressure afforded 3.572 $\mathrm{g}(82 \%)$ of $\mathbf{1 5 b}$ as hydrolytically sensitive colorless liquid that was stored under an atmosphere of nitrogen.

Data for $(E)-\mathbf{1 5 b}$ :

bp: $\quad 90-92{ }^{\circ} \mathrm{C}(0.04 \mathrm{mmHg})$

${ }^{1} \mathrm{H} \mathrm{NMR}: \quad\left(500 \mathrm{MHz}, \mathrm{CDCl}_{3}\right)$

7.37 (d, $J=7.6,2 \mathrm{H}, \mathrm{CH}(3)), 7.31$ (t, $J=7.6,2 \mathrm{H}, \mathrm{CH}(2)), 7.23$ (t, $J=7.3,1 \mathrm{H}$, $\mathrm{CH}(1)), 6.48(\mathrm{~d}, J=15.9,1 \mathrm{H}, \mathrm{CH}(5)), 6.31(\mathrm{dt}, J=15.8,7.0,1 \mathrm{H}, \mathrm{HC}(6)), 3.25$ (dd, $\left.2 \mathrm{H}, J=7.0,1.3,2 \mathrm{H}, \mathrm{CH}_{2}(7)\right), 0.31$ (s, $9 \mathrm{H}, \mathrm{CH}_{3}(9)$ )

${ }^{13} \underline{\mathrm{C} \mathrm{NMR}}: \quad\left(126 \mathrm{MHz}, \mathrm{CDCl}_{3}\right)$ $171.9(\mathrm{C}(8)), 136.8$ (C(4)), 132.9 (C(5)), 128.4 (C(2)), 127.3 (C(1)), 126.1 (C(3)), $122.1(\mathrm{C}(6)), 39.6(\mathrm{C}(7)),-0.4(\mathrm{C}(9))$

IR: (neat)

3083 (w), 3028 (m), 2961 (m), 2902 (m), 1717 (s), 1599 (w), 1578 (w), 1497 (m), 1449 (m), 1405 (w), 1358 (m), 1254 (s), 1197 (s), 1173 (s), 1067 (w), 1029 (w), 965 (m), 945 (m), 852 (s), 763 (m), 732 (m), 693 (m), $629(\mathrm{w})$

MS: $\quad(\mathrm{EI}, 70 \mathrm{eV})$

$234\left(\left(\mathrm{M}^{+}, 7\right), 190\right.$ (13), 115 (14), 75 (17), 73 (100)

Analysis: $\quad \mathrm{C}_{13} \mathrm{H}_{18} \mathrm{O}_{2} \mathrm{Si}$ (234.37)

Calcd: $\quad$ C, 66.62; H, 7.74\%

Found: $\quad$ C, 66.56; $\quad \mathrm{H}, 7.78 \%$ 


\section{Preparation of (E)-Triethylsilyl 4-Phenyl-3-butenoate (15c) [MGE-VII-36]}<smiles>O=C(O)C/C=C/c1ccccc1</smiles>

10

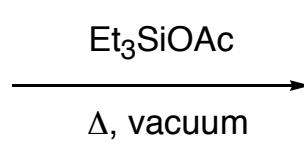

$\Delta$, vacuum

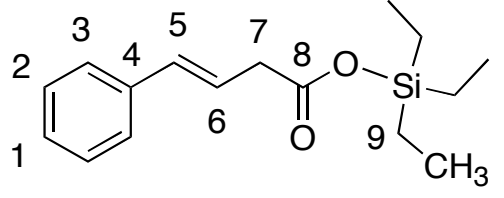

$15 c$ 10

A 15-mL, one neck, round-bottom flask equipped with a magnetic stir bar was charged with 4phenyl-3-butenoic acid 10 (1.303 g, $8.03 \mathrm{mmol}, 1.0$ equiv) followed by triethylsilyl acetate ( $2.10 \mathrm{~g}, 12.05 \mathrm{mmol}, 1.5$ equiv) and connected to a pre-arranged short-path distillation apparatus under an atmosphere of argon. The flask was immersed in an oil-bath pre-heated to $120{ }^{\circ} \mathrm{C}$ and the colorless solution stirred for $30 \mathrm{~min}$. A vacuum of $100 \mathrm{~mm} \mathrm{Hg}$ was then applied carefully to the distillation apparatus and a colorless liquid distilled over at $50-55{ }^{\circ} \mathrm{C}$. When the temperature of the distillate began to drop the oil-bath was heated further to $150{ }^{\circ} \mathrm{C}$ and more distillate obtained. In this manner, $831 \mathrm{mg}$ of colorless liquid identified by ${ }^{1} \mathrm{H}$ NMR as a 5:1 mixture of acetic acid and excess triethylsilyl acetate was obtained. Upon cessation of distillation, the vacuum was removed and replaced once more with an atmosphere of argon. The remainder of the liquid in the pot was distilled under reduced pressure to afford $1.517 \mathrm{~g}(68 \%)$ of $15 \mathrm{c}$ as a hydrolytically sensitive colorless liquid that was stored under an atmosphere of nitrogen.

\section{Data for $(E)-\mathbf{1 5 c}$ :}

bp: $\quad 96-98^{\circ} \mathrm{C}(0.05 \mathrm{mmHg})$

${ }^{1} \mathrm{H} \mathrm{NMR}: \quad\left(500 \mathrm{MHz}, \mathrm{CDCl}_{3}\right)$

$7.38(\mathrm{~d}, J=7.5,2 \mathrm{H}, \mathrm{CH}(3)), 7.31$ (t, $J=7.5,2 \mathrm{H}, \mathrm{CH}(2)), 7.23$ (tt, $J=7.3,1.3,1$ $\mathrm{H}, \mathrm{CH}(1)), 6.49$ (d, $J=15.9,1 \mathrm{H}, \mathrm{CH}(5)), 6.33$ (dt, $J=15.9,7.1,1 \mathrm{H}, \mathrm{HC}(6))$, $3.29\left(\mathrm{dd}, 2 \mathrm{H}, J=7.1,1.4,2 \mathrm{H}, \mathrm{CH}_{2}(7)\right), 1.00$ (t, $\left.J=7.8,9 \mathrm{H}, \mathrm{CH}_{3}(10)\right), 0.80$ (q, $J$ $\left.=7.8,6 \mathrm{H}, \mathrm{CH}_{2}(9)\right)$

${ }^{13} \mathrm{C} \mathrm{NMR}: \quad\left(126 \mathrm{MHz}, \mathrm{CDCl}_{3}\right)$ $172.0(\mathrm{C}(8)), 137.0(\mathrm{C}(4)), 133.0(\mathrm{C}(5)), 128.5$ (C(2)), $127.4(\mathrm{C}(1)), 126.2$ (C(3)), $122.3(\mathrm{C}(6)), 39.7(\mathrm{C}(7)), 6.4(\mathrm{C}(10)), 4.4(\mathrm{C}(9))$

IR: (neat) 3083 (w), 3062 (w), 3027 (m), 2957 (s), 2878 (s), 1719 (s), 1599 (w), 1496 (m), 1458 (m), 1412 (m), 1359 (m), 1293 (s), 1271 (s), 1172 (s), 1066 (w), 1007 (m), 
$964(\mathrm{~s}), 836(\mathrm{w}), 739(\mathrm{~s}), 692(\mathrm{~s})$

MS: $\quad(\mathrm{EI}, 70 \mathrm{eV})$

$$
276\left(\left(\mathrm{M}^{+}, 7\right), 247(59), 232 \text { (18), } 115 \text { (100), } 103 \text { (24), } 87 \text { (43), } 75\right. \text { (41) }
$$

Analysis: $\quad \mathrm{C}_{16} \mathrm{H}_{24} \mathrm{O}_{2} \mathrm{Si}(276.45)$

$\begin{array}{lll}\text { Calcd: } & \text { C, 69.51; } & \text { H, 8.75\% } \\ \text { Found: } & \text { C, 69.41; } & \text { H, 8.81\% }\end{array}$

\section{General Procedure 1. Preparation of Silyl Esters of 4-Phenyl-3-butenoic acid. Preparation of (E)-tert-Butyldimethylsilyl 4-Phenylbut-3-enoate (15d) [MGE-VII-24]}

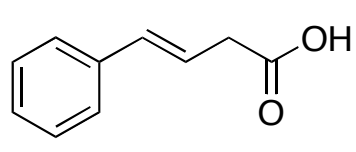

10

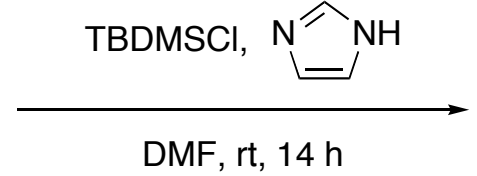

DMF, rt, $14 \mathrm{~h}$

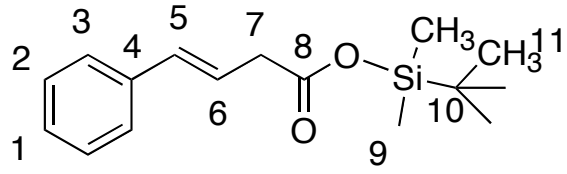

15d

A one-neck, 50-mL, round-bottom flask containing a magnetic stir bar was charged with 4-phenyl-3-butenoic acid 10 (600 mg, $3.70 \mathrm{mmol}, 1.0$ equiv) and imidazole (756 mg, 11.10 mmol, 3.0 equiv) A T-adaptor fitted with a rubber septum was connected to the flask and the contents placed under an atmosphere of nitrogen. DMF $(8 \mathrm{~mL})$ was added via syringe and the resulting colorless solution stirred at room temperature. To the stirred solution tertbutyldimethylsilyl chloride (836 mg, $5.55 \mathrm{mmol}, 1.5$ equiv) in DMF (8 mL) was added dropwise via syringe and the mixture stirred overnight $(14 \mathrm{~h})$ at room temperature. The reaction mixture was then transferred to a $125-\mathrm{mL}$ separatory funnel, diluted with pentane $(20 \mathrm{~mL})$ and extracted with water $(40 \mathrm{~mL})$. The aqueous layer was back-extracted with pentane $(2 \times 10 \mathrm{~mL})$, the combined organic extracts were pooled, washed with water $(20 \mathrm{~mL})$ followed by saturated brine $(30 \mathrm{~mL})$, and then were dried $\left(\mathrm{MgSO}_{4}\right)$, filtered and concentrated in vacuo to afford $1.22 \mathrm{~g}$ of a pale-yellow liquid. Bulb-to-bulb distillation afforded $957 \mathrm{mg}(94 \%)$ of 15d as a colorless liquid. Data for $(E)-\mathbf{1 5 d}$ :

bp: $\quad 160{ }^{\circ} \mathrm{C}(0.07 \mathrm{mmHg}, \mathrm{ABT})$

${ }^{1} \mathrm{H} \mathrm{NMR}: \quad\left(500 \mathrm{MHz}, \mathrm{CDCl}_{3}\right)$

7.37 (d, $J=7.3,2 \mathrm{H}, \mathrm{CH}(3)), 7.31$ (t, $J=7.6,2 \mathrm{H}, \mathrm{CH}(2)), 7.23$ (tt, $J=7.3,1.3,1$ $\mathrm{H}, \mathrm{CH}(1)), 6.48$ (d, $J=15.8,1 \mathrm{H}, \mathrm{CH}(5)), 6.31$ (dt, $J=15.8,7.1,1 \mathrm{H}, \mathrm{HC}(6))$, 
3.26 (dd, $\left.2 \mathrm{H}, J=7.1,1.4,2 \mathrm{H}, \mathrm{CH}_{2}(7)\right), 0.95$ (s, $\left.9 \mathrm{H}, \mathrm{CH}_{3}(11)\right), 0.29$ (s, $6 \mathrm{H}$, $\left.\mathrm{CH}_{3}(9)\right)$

${ }^{13} \mathrm{C} \mathrm{NMR}: \quad\left(126 \mathrm{MHz}, \mathrm{CDCl}_{3}\right)$

$172.0(\mathrm{C}(8)), 137.0(\mathrm{C}(4)), 133.1(\mathrm{C}(5)), 128.5(\mathrm{C}(2)), 127.4(\mathrm{C}(1)), 126.2(\mathrm{C}(3))$, 122.3 (C(6)), 39.9 (C(7)), 25.5 (C(11)), $17.6(\mathrm{C}(10)),-4.9$ (C(9))

IR: (neat)

3028 (w), 2956 (m), 2938 (m), 2886 (m), 2859 (m), 1720 (s), 1497 (w), 1472 (m), 1464 (m), 1449 (w), 1405 (w), 1363 (m), 1255 (s), 1198 (m), 1171 (m), $1006(\mathrm{w})$, 964 (m), 946 (m), 844 (s), 824 (s), 791 (s), 739 (m), 693 (m)

MS: $\quad\left(\mathrm{CI}, \mathrm{CH}_{4}\right)$

$277\left((\mathrm{M}+\mathrm{H})^{+}, 100\right), 261(47), 219(84), 145$ (29), 117 (65)

Analysis: $\quad \mathrm{C}_{16} \mathrm{H}_{24} \mathrm{O}_{2} \mathrm{Si}(276.45)$

Calcd: $\quad$ C, $69.51 ; \quad H, 8.75 \%$

Found: $\quad$ C, $69.17 ; \quad H, 8.85 \%$

\section{Preparation of (E)-Triisopropylsilyl 4-Phenyl-3-butenoate (15e) [MGE-VII-25]}<smiles>O=C(O)CC=Cc1ccccc1</smiles>

10

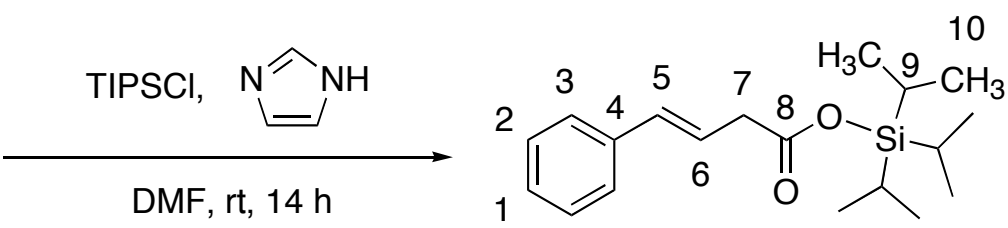

$15 e$

Following General Procedure 1, 4-phenyl-3-butenoic acid 10 (600 mg, 3.70 mmol, 1.0 equiv), imidazole (756 mg, $11.10 \mathrm{mmol}, 3.0$ equiv) and triisopropylsilyl chloride (1.070 g, 5.55 mmol, 1.5 equiv) were combined to yield, after column chromatography $\left(\mathrm{SiO}_{2}, 100 \mathrm{~g}, 50 \mathrm{~mm} \varnothing\right.$ $\times 10 \mathrm{~cm}, 30: 1$ hexanes $\left./ \mathrm{Et}_{2} \mathrm{O}, 800 \mathrm{~mL}\right), 1.063 \mathrm{~g}$ of a translucent liquid that was further purified by bulb-to-bulb distillation to yield $846 \mathrm{mg}(72 \%)$ of $15 \mathbf{e}$ as a colorless liquid.

$\underline{\text { Data for }(E)-\mathbf{1 5 e}}$

bp: $\quad 185^{\circ} \mathrm{C}(0.03 \mathrm{mmHg}, \mathrm{ABT})$

${ }^{1} \mathrm{H} \mathrm{NMR}: \quad\left(500 \mathrm{MHz}, \mathrm{CDCl}_{3}\right)$

$7.37(\mathrm{~d}, J=7.5,2 \mathrm{H}, \mathrm{CH}(3)), 7.31(\mathrm{t}, J=7.6,2 \mathrm{H}, \mathrm{CH}(2)), 7.23(\mathrm{tt}, J=7.3,1.3,1$ 
$\mathrm{H}, \mathrm{CH}(1)), 6.50(\mathrm{~d}, J=16.0,1 \mathrm{H}, \mathrm{CH}(5)), 6.33$ (dt, $J=15.8,7.1,1 \mathrm{H}, \mathrm{CH}(6))$, 3.29 (dd, $2 \mathrm{H}, J=7.1,1.4,2 \mathrm{H}, \mathrm{CH}_{2}(7)$ ), 1.32 (septet, $J=7.7 \mathrm{~Hz}, 3 \mathrm{H}, \mathrm{CH}(9)$ ), $1.09\left(\mathrm{~d}, J=7.5 \mathrm{~Hz}, 18 \mathrm{H}, \mathrm{CH}_{3}(10)\right)$

${ }^{13} \mathrm{C} \mathrm{NMR}: \quad\left(126 \mathrm{MHz}, \mathrm{CDCl}_{3}\right)$

$171.5(\mathrm{C}(8)), 137.0(\mathrm{C}(4)), 133.1(\mathrm{C}(5)), 128.5(\mathrm{C}(2)), 127.4(\mathrm{C}(1)), 126.2(\mathrm{C}(3))$, 122.4 (C(6)), 39.9 (C(7)), 17.7 (C(10)), 11.8 (C(9))

IR: (neat)

3027 (w), 2946 (s), 2893 (m), 2868 (s), 2859 (m), 1720 (s), 1600 (w), 1496 (w), 1465 (m), 1384 (w), 1358 (m), 1363 (m), 1293 (m), 1271 (m), 1197 (m), 1172 (m), 1069 (w), 1017 (w), 1000 (w), 964 (m), 945 (m), 883 (m), 736 (s), 690 (m)

MS: $\quad\left(\mathrm{CI}, \mathrm{CH}_{4}\right)$

$319\left((\mathrm{M}+\mathrm{H})^{+}, 43\right), 275$ (100), 157 (11)

TLC: $\quad R_{f} 0.31$ (hexanes/Et $\left.{ }_{2} \mathrm{O}, 30: 1\right)[\mathrm{CAM} / \Delta]$

Analysis: $\quad \mathrm{C}_{19} \mathrm{H}_{30} \mathrm{O}_{2} \mathrm{Si}(318.53)$

Calcd: $\quad$ C, $71.64 ; \quad$ H, $9.49 \%$

Found: $\quad$ C, $71.80 ; \quad$ H, $9.77 \%$

\section{Preparation of (E)-tert-Butyldiphenylsilyl 4-Phenyl-3-butenoate (15f) [MGE-VII-38]}<smiles>O=C(O)C/C=C/c1ccccc1</smiles>

10

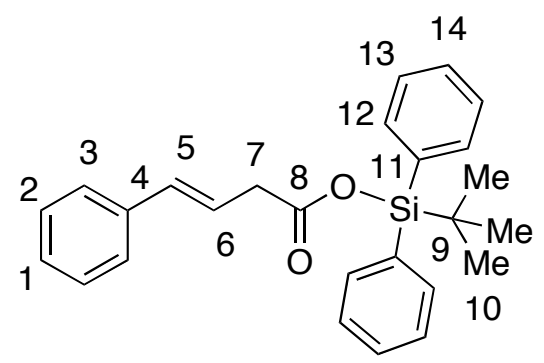

$15 f$

Following General Procedure 1, 4-phenyl-3-butenoic acid 10 (600 mg, 3.70 mmol, 1.0 equiv), imidazole (756 mg, $11.10 \mathrm{mmol}, 3.0$ equiv) and tert-butyldiphenylsilyl chloride (1.525 g, $5.55 \mathrm{mmol}, 1.5$ equiv) were combined to yield, after column chromatography $\left(\mathrm{SiO}_{2}, 100 \mathrm{~g}, 50\right.$ $\mathrm{mm} \varnothing \times 10 \mathrm{~cm}$, hexanes/ $\left.\mathrm{Et}_{2} \mathrm{O}, 20: 1800 \mathrm{~mL}\right), 1.319 \mathrm{~g}$ of a pale yellow liquid that was further purified by bulb-to-bulb distillation to yield $1.048 \mathrm{~g}(71 \%)$ of $\mathbf{1 5 f}$ as a colorless liquid. 


\section{Data for $(E)-\mathbf{1 5 f}$ :}

bp: $\quad 170{ }^{\circ} \mathrm{C}\left(4 \times 10^{-5} \mathrm{mmHg}, \mathrm{ABT}\right)$

${ }^{1} \mathrm{H} \mathrm{NMR}: \quad\left(500 \mathrm{MHz}, \mathrm{CDCl}_{3}\right)$

7.75 (dd d, $J=8.0,1.1,4$ H, CH(12)), 7.47 (tt, $J=7.3,1.4,2$ H. CH(14)), 7.39-

$7.42(\mathrm{~m}, 6 \mathrm{H}, \mathrm{CH}(3,13)), 7.37$ (t, $J=7.6,2 \mathrm{H}, \mathrm{CH}(2)), 7.27$ (tt, $J=7.3,1.3,1 \mathrm{H}$, $\mathrm{CH}(1)), 6.58(\mathrm{~d}, J=15.9,1 \mathrm{H}, \mathrm{CH}(5)), 6.43(\mathrm{dt}, J=15.9,7.1,1 \mathrm{H}, \mathrm{CH}(6)), 3.45$ (dd, $\left.2 \mathrm{H}, J=7.1,1.4,2 \mathrm{H}, \mathrm{CH}_{2}(7)\right), 1.17$ (s, $9 \mathrm{H}, \mathrm{CH}_{3}(10)$ )

${ }^{13} \underline{\mathrm{C} \mathrm{NMR}}: \quad\left(126 \mathrm{MHz}, \mathrm{CDCl}_{3}\right)$

170.6 (C(8)), 136.9 (C(4)), 135.3 (C(12)), 133.4 (C5)), 131.7 (C(11)), 130.1 (C(14)), 128.5 (C(2)), 127.7 (C(13)), 127.5 (C(1)), 126.2 (C(3)), 122.0 (C(6)), $40.1(\mathrm{C}(7)), 26.9$ (C(10)), 19.2 (C(9))

IR: (neat)

3073 (m), 3050 (m), 3027 (m), 3000 (m), 2959 (s), 2932 (s), 2894 (m), 2859 (s), 1728 (s), 1590 (w), 1495 (w), 1472 (m), 1448 (w), 1428 (s), 1393 (m), 1362 (m), 1293 (m), 1246 (s), 1664 (s), 1115 (s), 965 (s), 822 (m), 738 (s), 699 (s), 608 (m)

MS: $\quad(\mathrm{ESI})$

$418\left(\left(\mathrm{M}+\mathrm{NH}_{4}\right)^{+}, 88\right), 341(22), 323(29), 281$ (100), 263 (13)

TLC: $\quad R_{f} 0.30($ hexanes/Et $2 \mathrm{O}, 20: 1)[\mathrm{CAM} / \Delta]$

Analysis: $\quad \mathrm{C}_{26} \mathrm{H}_{28} \mathrm{O}_{2} \mathrm{Si}(400.58)$

Calcd: $\quad$ C, 77.96; $\quad \mathrm{H}, 7.05 \%$

Found: $\quad$ C, $77.81 ; \quad H, 7.02 \%$

\section{Preparation of (E)-Methyl 4-phenyl-3-butenoate (15g) ${ }^{9}$ [MGE-VII-72]}

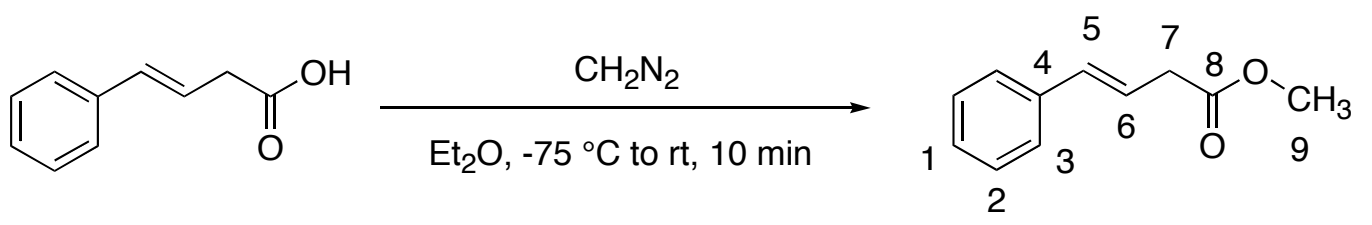

10

$15 g$

A solution of diazomethane in diethyl ether (3.70-4.75 mmol, 1.2-1.5 equiv) was prepared according to the Aldrich procedure ${ }^{10}$ in a fire polished diazomethane generation kit. A solution 
of Diazald (1.111 g, $5.19 \mathrm{mmol}, 1.68$ equiv) in diethyl ether was added dropwise over 20 min to a stirred solution of potassium hydroxide $(1.111 \mathrm{~g}, 19.80 \mathrm{mmol})$ in ethanol $(2.25 \mathrm{~mL})$ and water $(1.75 \mathrm{~mL})$. The ethereal diazomethane solution thus generated was distilled directly into a stirred solution of 4-phenyl-3-butenoic acid (500 mg, $3.08 \mathrm{mmol}, 1.0$ equiv) in diethyl ether (5 mL) maintained at $-75{ }^{\circ} \mathrm{C}$ (bath temperature, $i \mathrm{ProH} / \mathrm{CO}_{2}$ ). Upon cessation of distillation two further portion of diethyl ether $(2 \times 2 \mathrm{~mL})$ were added to the generator flask to ensure complete distillation of any diazomethane generated. The reaction mixture was then removed from the cool bath and allowed to stir for $10 \mathrm{~min}$ with warming to room temperature. The resulting yellow solution was quenched by the careful dropwise addition of acetic acid $(250 \mu \mathrm{L})$ in diethyl ether $(5 \mathrm{~mL})$ whereupon the color was discharged. The reaction mixture was then poured into a $60 \mathrm{~mL}$ separatory funnel containing saturated sodium bicarbonate solution $(20 \mathrm{~mL})$ and the layers were separated. The organic layer was washed with saturated brine $(20 \mathrm{~mL})$, dried $\left(\mathrm{MgSO}_{4}\right)$, filtered and concentrated in vacuo to yield $520 \mathrm{mg}$ of a pale yellow liquid. Bulb-to-bulb distillation under reduced pressure afforded $509 \mathrm{mg}(94 \%)$ of $\mathbf{1 5 g}$ as a colorless liquid.

Data for $(E)-\mathbf{1 5 g}$ :

bp: $\quad 90{ }^{\circ} \mathrm{C}(0.06 \mathrm{~mm} \mathrm{Hg}, \mathrm{ABT})$

${ }^{1} \mathrm{H} \mathrm{NMR}: \quad\left(500 \mathrm{MHz}, \mathrm{CDCl}_{3}\right)$

$7.41(\mathrm{~d}, J=7.6,2 \mathrm{H}, \mathrm{CH}(3)), 7.34$ (t, $J=7.6,2 \mathrm{H}, \mathrm{CH}(2)), 7.26$ (t, $J=7.3,1 \mathrm{H}$, $\mathrm{CH}(1)), 6.52$ (br. d, $J=15.9,1 \mathrm{H}, \mathrm{CH}(5)), 6.33$ (dt, $J=15.7,7.2,1 \mathrm{H}, \mathrm{CH}(6)$ ), 3.74 (s, $3 \mathrm{H}, \mathrm{CH}_{3}(9), 3.29$ (dd, $J=7.1,1.5,2 \mathrm{H}, \mathrm{CH}_{2}(7)$ )

${ }^{13} \mathrm{C} \mathrm{NMR}: \quad\left(126 \mathrm{MHz}, \mathrm{CDCl}_{3}\right)$

$172.0(\mathrm{C}(8)), 136.7(\mathrm{C}(4)), 133.4(\mathrm{C}(5)), 128.5(\mathrm{C}(2)), 127.5(\mathrm{C}(1)), 126.2(\mathrm{C}(3))$, $121.6(\mathrm{C}(6)), 51.9(\mathrm{C}(9)), 38.1(\mathrm{C}(7))$

IR: (neat)

3083 (w), 3027 (m), 2952 (m), 1739 (s), 1599 (w), 1578 (w), 1497 (m), 1449 (m), 1435 (s), 1407 (m), 1356 (m), 1320 (m), 1294 (m), 1254 (s), 1201 (s), 1163 (s), $1066(\mathrm{w}), 1013(\mathrm{~m}), 966(\mathrm{~s}), 940(\mathrm{w}), 897(\mathrm{w}), 856(\mathrm{w}), 831(\mathrm{w}), 747(\mathrm{~s}), 693$ (s)

MS: $\quad(\mathrm{EI}, 70 \mathrm{eV})$

$176\left(\left(\mathrm{M}^{+}, 40\right), 117(100), 115(34), 91(16)\right.$ 


\section{Preparation of (E)-Neopentyl 4-Phenyl-3-butenoate (15h) [MGE-VII-80]}

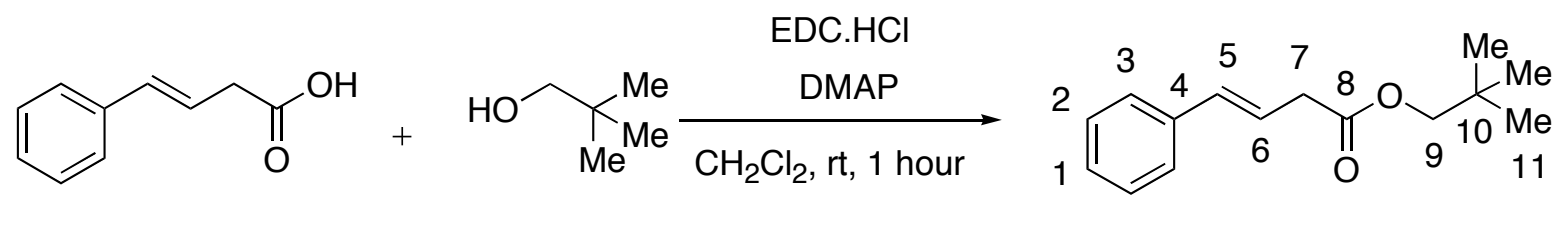

10

$15 h$

A 50-mL, one-neck, round-bottom flask containing a magnetic stir bar was charged with 4phenyl-3-butenoic acid 10 (500 mg, 3.08 mmol, 1.0 equiv), 2,2-dimethyl-1-propan-ol (272 mg, $3.08 \mathrm{mmol}, 1.0$ equiv) and 4-dimethylaminopyridine [DMAP] (75 mg, $0.616 \mathrm{mmol}, 0.2 \mathrm{equiv})$. A T-adaptor fitted with a rubber septum was attached and the contents of the flask placed under an atmosphere of argon. $\mathrm{CH}_{2} \mathrm{Cl}_{2}(5 \mathrm{~mL})$ was added and the colorless solutionstirred vigorously. EDC.HCl (768 mg, $4.00 \mathrm{mmol}, 1.3$ equiv) was added in a single portion and the resulting pale yellow solution was stirred at room temperature until the reaction was judged to be complete by TLC (1 h). The reaction mixture was diluted with $\mathrm{CH}_{2} \mathrm{Cl}_{2}(20 \mathrm{~mL})$, transferred to a $125-\mathrm{mL}$ separatory funnel and was washed with $1 \mathrm{M} \mathrm{HCl}(30 \mathrm{~mL})$. The aqueous extract was backextracted with $\mathrm{CH}_{2} \mathrm{Cl}_{2}(2 \times 10 \mathrm{~mL})$, the organic layers were combined, washed with saturated brine $(50 \mathrm{~mL})$, dried $\left(\mathrm{MgSO}_{4}\right)$, filtered and concentrated in vacuo to yield $816 \mathrm{mg}$ of a yellow liquid. The crude material was loaded directly onto a silica column and purified by column chromatography $\left(\mathrm{SiO}_{2}, 75 \mathrm{~g}, 50 \mathrm{~mm} \varnothing \times 7 \mathrm{~cm}\right.$, hexanes/Et $2 \mathrm{O}, 25: 1(750 \mathrm{~mL})$ to afford $620 \mathrm{mg}$ of a colorless liquid. This material was further purified by bulb-to-bulb distillation to afford 581 $\mathrm{mg}(81 \%)$ of a $\mathbf{1 5 h}$ as a colorless liquid.

Data for $(E)-\mathbf{1 5 h}$ :

bp: $\quad 155^{\circ} \mathrm{C}(0.11 \mathrm{~mm} \mathrm{Hg}, \mathrm{ABT})$

${ }^{1} \mathrm{H} \mathrm{NMR}: \quad\left(500 \mathrm{MHz}, \mathrm{CDCl}_{3}\right)$

$7.39(\mathrm{~d}, J=7.3,2 \mathrm{H}, \mathrm{CH}(3)), 7.34(\mathrm{t}, J=7.6,2 \mathrm{H}, \mathrm{CH}(2)), 7.26(\mathrm{tt}, J=7.3,1.2,1$ $\mathrm{H}, \mathrm{CH}(1)), 6.52$ (d, $J=15.9,1 \mathrm{H}, \mathrm{CH}(5)), 6.33$ (dt, $J=15.9,7.2,1 \mathrm{H}, \mathrm{CH}(6))$, 3.85 (s, $\left.2 \mathrm{H}, \mathrm{CH}_{2}(9)\right), 3.29$ (dd, $\left.J=7.2,1.2,2 \mathrm{H}, \mathrm{CH}_{2}(7)\right), 0.98$ (s, $9 \mathrm{H}, \mathrm{CH}_{3}(11)$ )

${ }^{13} \mathrm{C} \mathrm{NMR}: \quad\left(126 \mathrm{MHz}, \mathrm{CDCl}_{3}\right)$

171.5 (C(4)), 136.8 (C(8)), 133.3 (C(7)), 128.5 (C(10)), 127.4 (C(11)), 126.2 (C(9)), 73.9 (C(3)), $38.4(\mathrm{C}(5)), 31.3(\mathrm{C}(2)), 26.4(\mathrm{C}(1))$ 
IR: (neat)

3083 (w), 3060 (w), 3027 (m), 2959 (s), 2904 (m), 2870 (m), 1946 (w), 1875 (w), 1736 (s), 1655 (w), 1599 (w), 1578 (w), 1496 (m), 1478 (m), 1465 (m), 1449 (m), 1401 (m), 1367 (s), 1349 (w), 1293 (m), 1272 (s), 1248 (s), 1159 (s), 1063 (w), $995(\mathrm{~m}), 965$ (s), $913(\mathrm{w}), 836(\mathrm{w}), 812(\mathrm{w}), 744(\mathrm{~s}), 692$ (s)

MS: $\quad(\mathrm{EI}, 70 \mathrm{eV})$ $232\left(\left(\mathrm{M}^{+}, 54\right), 118(21), 117(100), 116(18), 115(38), 91\right.$ (18), 57 (19), 55 (12)

TLC: $\quad R_{f} 0.38$ (hexanes/Et $\left.{ }_{2} \mathrm{O}, 25: 1\right),[\mathrm{CAM} / \Delta]$

Analysis: $\quad \mathrm{C}_{15} \mathrm{H}_{20} \mathrm{O}_{2}(232.32)$

Calcd: $\quad$ C, $77.55 ; \quad \mathrm{H}, 8.68 \%$

Found: $\quad \mathrm{C}, 77.59 ; \quad \mathrm{H}, 8.71 \%$

\subsection{Preparation of Carboxylic Acid 23}

Preparation of 4-(2-Methylphenyl)-3-butyn-1-ol (20) [MGE-VII-49]

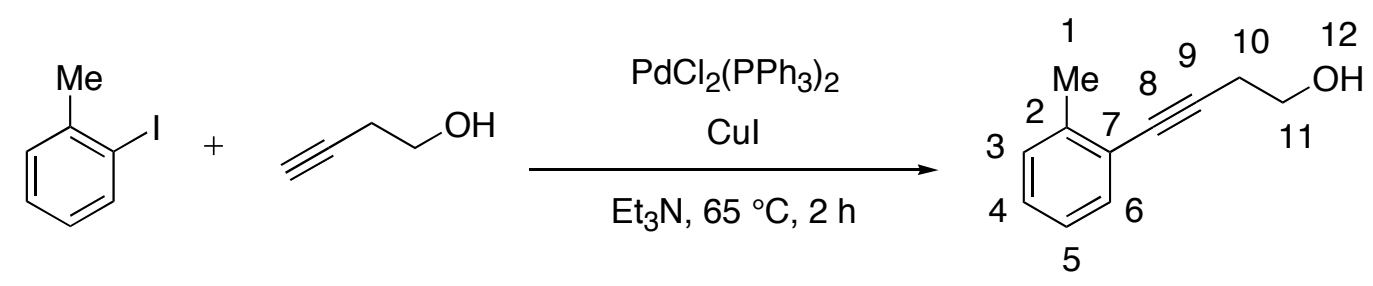

20

An oven-dried, 250-mL, 3-neck round-bottom flask equipped with a magnetic stir bar was charged with dichlorobis(triphenylphosphine)palladium(II) (965 mg, $1.376 \mathrm{mmol}, 0.06$ equiv), copper (I) iodide (131 mg, $0.688 \mathrm{mmol}, 0.03$ equiv) and s-tolyl iodide (5.00 g, $22.93 \mathrm{mmol}, 1.0$ equiv). Triethylamine $(115 \mathrm{~mL})$ was added, the flask was fitted with an argon inlet adaptor and was purged with argon for 15 min. The flask was then sealed under an atmosphere of argon, and 3-butyn-1-ol added via syringe (1.928 g, $2.08 \mathrm{~mL}, 27.51 \mathrm{mmol}, 1.2$ equiv) with vigorous stirring. The flask was transferred to an oil-bath pre-heated to $65^{\circ} \mathrm{C}$ and was heated at this temperature until the reaction was judged to be complete by TLC $(2 \mathrm{~h})$. After cooling to room temperature the dark-green slurry was filtered through a $5 \mathrm{~cm}$ celite plug and the solids were washed with $\mathrm{Et}_{2} \mathrm{O}$ 
$(2 \times 20 \mathrm{~mL})$. Concentration of the filtrate in vacuo afforded $3.782 \mathrm{~g}$ of a brown oil. The crude material was loaded directly onto a silica column and was purified by column chromatography $\left(\mathrm{SiO}_{2}, 150 \mathrm{~g}, 50 \mathrm{~mm} \varnothing \times 13 \mathrm{~cm}\right.$, hexanes/Et $2 \mathrm{O}, 2: 1,2 \mathrm{~L}$ ) to afford $3.391 \mathrm{~g}$ of a yellow liquid. Subsequent bulb-to-bulb distillation afforded $3.329 \mathrm{~g}(91 \%)$ of $\mathbf{2 0}$ as a colorless liquid.

Data for 20:

bp: $\quad 125^{\circ} \mathrm{C}(0.05 \mathrm{mmHg}, \mathrm{ABT})$

${ }^{1}$ H NMR: $\quad\left(500 \mathrm{MHz}, \mathrm{CDCl}_{3}\right)$

7.39 (br. d, $J=7.4,1 \mathrm{H}, \mathrm{CH}(6)$ ), 7.18-7.21 (m, $2 \mathrm{H}, \mathrm{CH}(3,4))$, 7.10-7.15 (m, $1 \mathrm{H}$, $\mathrm{CH}(5)), 3.82$ (q, $\left.J=6.3,2 \mathrm{H}, \mathrm{CH}_{2}(11)\right), 2.73$ (t, $\left.J=6.4,2 \mathrm{H}, \mathrm{CH}_{2}(10)\right), 2.43$ (s, 3 $\left.\mathrm{H}, \mathrm{CH}_{3}(1)\right), 2.33$ (br. m, $\mathrm{OH}(13)$ )

${ }^{13}$ C NMR: $\quad\left(126 \mathrm{MHz}, \mathrm{CDCl}_{3}\right)$ $139.9(\mathrm{C}(2)), 131.8(\mathrm{C}(6)), 129.3(\mathrm{C}(3)), 127.8(\mathrm{C}(4)), 125.4(\mathrm{C}(5)), 123.0(\mathrm{C}(7))$, $90.2(\mathrm{C}(9)), 81.2(\mathrm{C}(8)), 61.2(\mathrm{C}(11)), 23.8(\mathrm{C}(10)), 20.6(\mathrm{C}(1))$

IR: (neat) 3349 (s), 3062 (m), 3021 (m), 2944 (s), 2920 (s), 1600 (w), 1485 (s), $1456(\mathrm{~m})$, 1431 (m), 1379 (m), 1333 (m), 1290 (w), 1184 (w), 1115 (m), 1043 (s), 943 (w), $889(\mathrm{w}), 846(\mathrm{~m}), 756(\mathrm{~s}), 716(\mathrm{~s}), 679(\mathrm{w})$

MS: $\quad(E I, 70 \mathrm{eV})$

$160\left(\left(\mathrm{M}^{+}, 100\right), 130\right.$ (37), 129 (98), 119 (13), 77 (13)

TLC: $\quad R_{f} 0.23$ (hexanes/ $\left./ \mathrm{Et}_{2} \mathrm{O}, 2: 1\right)\left[\mathrm{UV}+\mathrm{KMnO}_{4} / \Delta\right]$

Analysis: $\quad \mathrm{C}_{11} \mathrm{H}_{12} \mathrm{O}(160.21)$

Calcd: $\quad$ C, $82.46 ; \quad$ H, $7.55 \%$

Found: $\quad$ C, $82.41 ; \quad H, 7.68 \%$ 


\section{Preparation of (E)-4-(2-Methylphenyl)-3-buten-1-ol (21) [MGE-VII-52]}

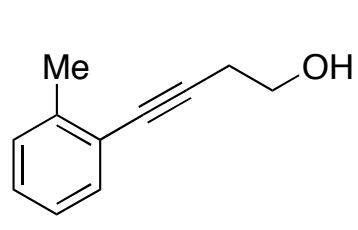

20

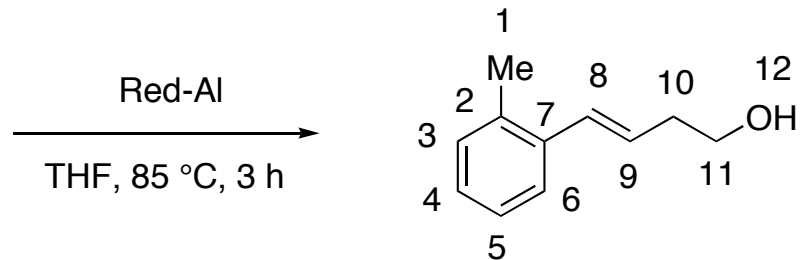

21

To a flame-dried, 250-mL, 3-neck flask equipped with a reflux condenser mounted with a gas inlet adaptor, a septum (pierced with thermocouple probe) and a magnetic stir bar under an atmosphere of argon were placed 4-(2-methylphenyl)-3-butyn-1-ol 20 (2.87 g, $17.91 \mathrm{mmol}, 1.0$ equiv) and THF (36 mL) The solution was cooled to $0{ }^{\circ} \mathrm{C}$ using an ice bath and sodium methoxyethoxyaluminium hydride [1.62 $\mathrm{M}$ in toluene] $(13.33 \mathrm{~mL}, 21.50 \mathrm{mmol}, 1.2$ equiv) was added dropwise via syringe maintaining the internal temperature below $12{ }^{\circ} \mathrm{C}$; the initial addition was accompanied by the vigorous evolution of gas. Upon completion of the addition the reaction flask was transferred to an oil-bath and was heated at $85{ }^{\circ} \mathrm{C}$ (bath-temperature) for $3 \mathrm{~h}$. The resulting purple colored solution was cooled to $0{ }^{\circ} \mathrm{C}$ using an ice bath and the reaction mixture was carefully quenched by the dropwise addition of $2 \mathrm{M}$ aqueous $\mathrm{H}_{2} \mathrm{SO}_{4}(13.5 \mathrm{~mL})$ maintaining the internal temperature below $15{ }^{\circ} \mathrm{C}$. The biphasic mixture was transferred to a $500-\mathrm{mL}$ separatory funnel, diluted with $\mathrm{Et}_{2} \mathrm{O}(100 \mathrm{~mL})$ and water $(100 \mathrm{~mL})$ and the phases were separated. The aqueous layer was extracted with $\mathrm{Et}_{2} \mathrm{O}(2 \times 50 \mathrm{~mL})$. The combined organic layers were washed with saturated brine $(200 \mathrm{~mL})$, dried $\left(\mathrm{MgSO}_{4}\right)$, filtered and concentrated in vacuo to afford $2.76 \mathrm{~g}$ of a pale yellow oil. The crude material was loaded directly onto a silica column and purified by column chromatography $\left(\mathrm{SiO}_{2}, 110 \mathrm{~g}, 50 \mathrm{~mm} \varnothing \times 10 \mathrm{~cm}\right.$, hexanes/Et $\mathrm{O}_{2}$, $2: 1,1.75 \mathrm{~L})$ to afford $2.39 \mathrm{~g}$ of a yellow liquid. Subsequent bulb-to-bulb distillation afforded $2.322 \mathrm{~g}(80 \%)$ of $\mathbf{2 1}$ as a colorless liquid.

Data for $(E)-21$ :

bp: $\quad 145^{\circ} \mathrm{C}(0.06 \mathrm{mmHg}, \mathrm{ABT})$

${ }^{1} \mathrm{H} \mathrm{NMR}: \quad\left(500 \mathrm{MHz}, \mathrm{CDCl}_{3}\right)$

$7.46(\mathrm{~m}, 1 \mathrm{H}, \mathrm{CH}(6)), 7.15-7.20(\mathrm{~m}, 3 \mathrm{H}, \mathrm{CH}(3,4,5)), 6.72(\mathrm{~d}, J=15.7,1 \mathrm{H}$, $\mathrm{CH}(8)), 6.10(\mathrm{dt}, J=15.6,7.1,1 \mathrm{H}, \mathrm{CH}(9)), 3.77$ (t, $\left.J=6.4,2 \mathrm{H}, \mathrm{CH}_{2}(11)\right), 2.53$ 
(ddt, $\left.J=7.1,6.4,1.3,2 \mathrm{H}, \mathrm{CH}_{2}(10)\right), 2.37$ (s, $3 \mathrm{H}, \mathrm{CH}_{3}(1)$ ), 1.97-2.01 (br. m, $\mathrm{OH}(12))$

${ }^{13} \mathrm{C}$ NMR: $\quad\left(126 \mathrm{MHz}, \mathrm{CDCl}_{3}\right)$

$136.3(\mathrm{C}(7)), 134.9(\mathrm{C}(2)), 130.5$ (C(8)), 130.1 (C(4)), 127.6 (C(9)), $127.1(\mathrm{C}(5))$, 126.0 (C(3)), 125.4 (C(6)), 62.1 (C(11)), 36.6 (C(10)), 19.7 (C(1))

IR: (neat)

3388 (s), 3060 (m), 3020 (m), 2928 (s), 2878 (s), 1649 (w), 1601 (w), 1484 (s), 1460 (s), 1379 (m), 1222 (w), 1185 (w), $1110(w), 1045$ (s), 965 (s), 895 (w), 865 (w), $746(\mathrm{~s}), 715(\mathrm{~m}), 614(\mathrm{w})$

MS: $\quad(\mathrm{EI}, 70 \mathrm{eV})$

$162\left(\left(\mathrm{M}^{+}, 100\right), 129(17), 116(33), 115(30), 91(35)\right.$

TLC: $\quad R_{f} 0.19$ (hexanes/ $\left.\mathrm{Et}_{2} \mathrm{O}, 2: 1\right)\left[\mathrm{UV}+\mathrm{KMnO}_{4} / \Delta\right]$

Analysis: $\quad \mathrm{C}_{11} \mathrm{H}_{14} \mathrm{O}(162.23)$

Calcd: $\quad$ C, 81.44; H, 8.70\%

Found: $\quad \mathrm{C}, 81.26 ; \quad \mathrm{H}, 8.92 \%$

\section{Preparation of (E)-4-(2-Methylphenyl)but-3-enal (22) [MGE-VII-53]}

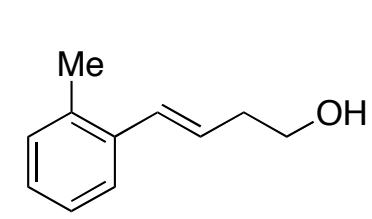

21

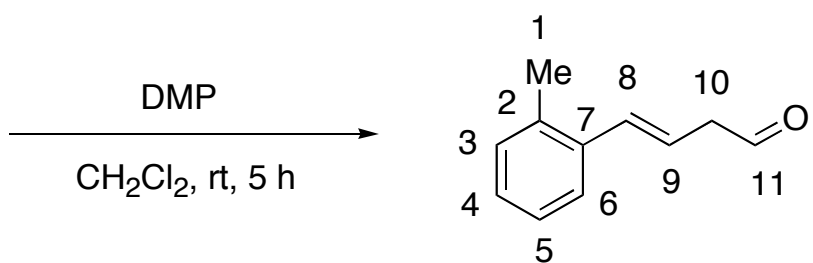

22

To a flame-dried, 250-mL, 3-neck flask equipped with a gas inlet adaptor and a magnetic stir bar under an atmosphere of argon were placed 1,1,1-triacetoxy-1,1-dihydro-1,2-benziodoxol-3(1H)one [DMP] (11.287 g, $26.610 \mathrm{mmol}, 1.5$ equiv) and $\mathrm{CH}_{2} \mathrm{Cl}_{2}(80 \mathrm{~mL})$. A solution of $(E)-4(-2-$ methylphenyl)-3-buten-1-ol 21 (2.878 g, $17.74 \mathrm{mmol})$ in $\mathrm{CH}_{2} \mathrm{Cl}_{2}(15 \mathrm{~mL})$ added dropwise via syringe and the colorless solution stirred at room temperature until the reaction was judged to be complete by TLC (6 hours). The reaction mixture was then poured into a 1-L Erlenmeyer flask containing a stirred solution of $\mathrm{Et}_{2} \mathrm{O}(300 \mathrm{~mL})$ and a solution of $45 \mathrm{~g}$ of sodium thiosulfate in 450 
$\mathrm{mL}$ of saturated aqueous sodium bicarbonate added. After being stirred for $15 \mathrm{~min}$ the mixture was transferred to a 1-L separatory funnel and the phases were separated. The aqueous layer was further extracted with $\mathrm{Et}_{2} \mathrm{O}(2 \times 100 \mathrm{~mL})$ and the organic extracts were combined, washed with saturated brine $(250 \mathrm{~mL})$, dried $\left(\mathrm{MgSO}_{4}\right)$, filtered and concentrated in vacuo to afford $3.01 \mathrm{~g}$ of 22 as an unstable yellow liquid that decomposed readily. This material was used immediately in the subsequent oxidation step without purification.

An analytical sample of the product was obtained from a similar reaction run on a $100 \mathrm{mg}(0.616$ mmol) scale. The crude aldehyde product was purified by bulb-to-bulb distillation under reduced pressure to afford $62 \mathrm{mg}(63 \%)$ of $\mathbf{2 2}$ as a colorless liquid.

Data for $(E)-\mathbf{2 2}$ :

bp: $\quad 110^{\circ} \mathrm{C}(1 \mathrm{mmHg}, \mathrm{ABT})$

${ }^{1}$ H NMR: $\quad\left(500 \mathrm{MHz}, \mathrm{CDCl}_{3}\right.$ )

$9.86(\mathrm{t}, J=1.9,1 \mathrm{H}, \mathrm{CH}(11)), 7.56-7.58(\mathrm{~m}, 1 \mathrm{H}, \mathrm{CH}(6)), 7.20-7.30(\mathrm{~m}, 3 \mathrm{H}$, $\mathrm{CH}(3,4,5)), 6.84(\mathrm{dt}, J=15.8,1.4,1 \mathrm{H}, \mathrm{CH}(8)), 6.26(\mathrm{dt}, J=15.8,7.1,1 \mathrm{H}$, $\mathrm{CH}(9)), 3.46$ (dt, $\left.J=7.1,1.7,2 \mathrm{H}, \mathrm{CH}_{2}(10)\right), 2.44$ (s, $\left.3 \mathrm{H}, \mathrm{CH}_{3}(1)\right)$

${ }^{13}$ C NMR: $\quad\left(126 \mathrm{MHz}, \mathrm{CDCl}_{3}\right)$

$199.5(\mathrm{C}(11)), 135.8,135.2,133.0(\mathrm{C}(8)), 130.3,127.7,126.1,125.6,120.5$, C(9)), 47.7, C(10)), 19.7 (C(1))

IR: (neat)

3021 (m), 2949 (m), 2824 (m), 2726 (m), 1723 (s), 1679 (m), 1647 (m), 1601 (m), 1484 (s), 1460 (m), 1382 (m), 1291 (w), 1223 (w), 1185 (w), 1110 (w), 10839 (m), $1034(\mathrm{~m}), 966(\mathrm{~s}), 904(\mathrm{w}), 750(\mathrm{~s}), 614(\mathrm{w})$

TLC: $\quad R_{f} 0.64\left(\mathrm{Et}_{2} \mathrm{O} /\right.$ hexanes, $\left.2: 1\right)[\mathrm{CAM} / \Delta]$ 


\section{Preparation of (E)-4-(2-Methylphenyl)-3-butenoic acid (23) [MGE-VII-59]}

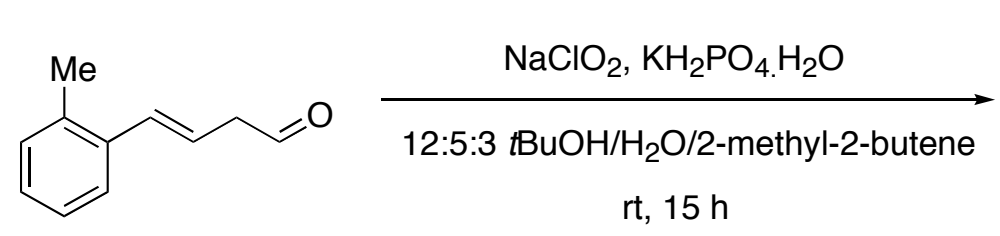

22

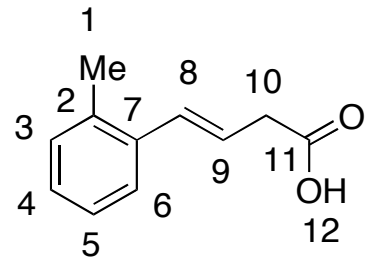

23

A 1-L, 1-neck, round-bottom flask containing a magnetic stir bar and the crude aldehyde product 22 (17.74 mmol, 1.0 equiv) was charged with tert-butanol $(400 \mathrm{~mL})$ and 2-methyl-2-butene (100 $\mathrm{mL}$ ) and the pale-yellow solution stirred vigorously. A $250 \mathrm{~mL}$ pressure-equalizing dropping funnel was attached to the flask and charged with a solution of sodium chlorite [80\% w/w] (6.416 g, $53.22 \mathrm{mmol}, 3.0$ equiv) and potassium dihydrogenphosphate monohydrate (7.343 g, $53.22 \mathrm{mmol}, 3.0$ equiv) in water $(150 \mathrm{~mL})$. The aqueous solution was added dropwise to the reaction mixture over $30 \mathrm{~min}$ and the reaction mixture was stirred overnight at room temperature (15 h). The volatiles were removed by concentration in vacuo and the remainder was transferred to a 1-L Erlenmeyer flask, then was diluted with water $(300 \mathrm{~mL})$ and acidified carefully to $\mathrm{pH} 3-$ 4 ( $\mathrm{pH}$ paper) by the dropwise addition of $1 \mathrm{M}$ aqueous $\mathrm{HCl}$ solution $(30 \mathrm{~mL})$. [CARE: Acidification beyond this point leads to the formation of the significant amounts of the cyclization product, 2-tolylbutyrolactone, and other by-products.] The mixture was transferred to a 1-L separatory funnel and was extracted with EtOAc $(4 \times 100 \mathrm{~mL})$. The combined organic extracts were washed with saturated brine $(250 \mathrm{~mL})$, dried $\left(\mathrm{MgSO}_{4}\right)$, filtered and concentrated in vacuo to afford $3.06 \mathrm{~g}$ of a yellow oil. The crude material was loaded directly onto a silica column and purified by column chromatography $\left(\mathrm{SiO}_{2}, 150 \mathrm{~g}, 50 \mathrm{~mm} \varnothing \times 12 \mathrm{~cm}\right.$, hexanes/Et ${ }_{2} \mathrm{O}$, 4:1 (1 L) then 100:100:1 hexanes/ $\left.\mathrm{Et}_{2} \mathrm{O} / \mathrm{AcOH},(1 \mathrm{~L})\right)$ to afford $2.460 \mathrm{~g}$ of a pale yellow liquid. This material was further purified by bulb-to-bulb distillation to afford $2.125 \mathrm{~g}$ (68\%, 2 steps) of a colorless liquid that solidified as a waxy cream solid upon cooling. Analytically pure material was obtained by recrystallization from toluene/hexane. The waxy solid was dissolved in $4 \mathrm{~mL}$ of hot toluene and cooled to $-13{ }^{\circ} \mathrm{C}$ (freezer). Hexane $(10 \mathrm{~mL})$ was then added and the mixture recooled to $-13{ }^{\circ} \mathrm{C}$ for 1 hour (freezer) to afford colorless plates of the product. The crystals were filtered cold, not washed with further solvent (this leads only to further losses in mass recovery) 
and dried under high vacuum $(0.03 \mathrm{~mm} \mathrm{Hg})$ to afford $1.169 \mathrm{~g}(37 \%, 2$ steps $)$ of 23 as colorless plates.

Data for $(E)-\mathbf{2 3}$ :

mp: $\quad 53-55^{\circ} \mathrm{C}($ toluene/hexane)

${ }^{1} \mathrm{H}$ NMR: $\quad\left(500 \mathrm{MHz}, \mathrm{CDCl}_{3}\right)$

11.66 (br. s, $1 \mathrm{H}, \mathrm{OH}(12))$, 7.43-7.48 (m, $1 \mathrm{H}, \mathrm{CH}(6))$, 7.13-7.17 (m, $3 \mathrm{H}$, $\mathrm{CH}(3,4,5)), 6.84(\mathrm{~d}, J=15.7,1 \mathrm{H}, \mathrm{CH}(8)), 6.26$ (dt, $J=15.7,7.2,1 \mathrm{H}, \mathrm{CH}(9))$, $3.46\left(\mathrm{dd}, J=7.1,1.4,2 \mathrm{H}, \mathrm{CH}_{2}(10)\right), 2.35$ (s, $\left.3 \mathrm{H}, \mathrm{CH}_{3}(1)\right)$

${ }^{13} \mathrm{C} \mathrm{NMR}: \quad\left(126 \mathrm{MHz}, \mathrm{CDCl}_{3}\right)$

178.5 (C(11)), 135.7 (C(7)), 135.2 (C(2)), 131.8 (C(8)), 130.2 (C(3)), 127.6 (C(5)), 126.1 (C(4)), 125.7 (C(6)), 122.0, C(9)), 38.3, C(10)), 19.7 (C(1))

IR: $\quad\left(\mathrm{CH}_{2} \mathrm{Cl}_{2}\right)$

3070 (br. m), 2956 (m), 2731 (m), 1946 (w), 1912 (w), 1879 (w), 1721 (s), 1601

(w), 1483 (m), 1461 (m), 1402 (s), 1340 (m), 1303 (m), 1215 (s), 1112 (w), 1053

(m), 1034 (m), 978 (m), 968 (s), 936 (m), 876 (br. m), 751 (s), 716 (m), 666 (m)

MS: $\quad(\mathrm{EI}, 70 \mathrm{eV})$

$176\left(\left(\mathrm{M}^{+}, 59\right), 131(100), 117(12), 116(36), 115\right.$ (31), 91 (27)

TLC: $\quad R_{f} 0.38$ (hexanes/ $\left.\mathrm{Et}_{2} \mathrm{O} / \mathrm{AcOH} 100: 100: 1\right)[\mathrm{CAM} / \Delta]$

Analysis: $\quad \mathrm{C}_{11} \mathrm{H}_{12} \mathrm{O}_{2}(176.21)$

Calcd: $\quad$ C, 74.98; H, 6.86\%

Found: $\quad$ C, $74.87 ; \quad H, 6.84 \%$ 


\subsection{Preparative Selenocyclization Reactions}

\section{Preparation of $( \pm)-(4 R S, \quad 5 S R)-D i h y d r o-4-(p h e n y l s e l e n o)-5-p h e n y l f u r a n-2(3 H)-o n e \quad(11)^{7}$ [MGE-VII-48]}

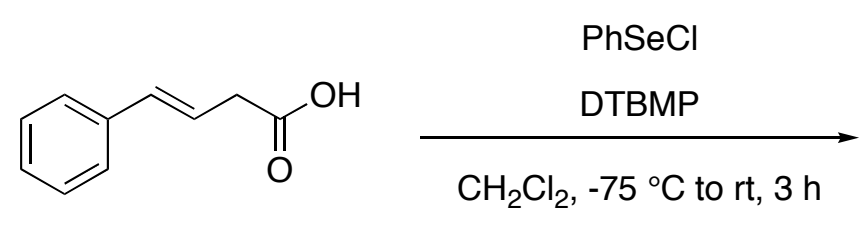

10

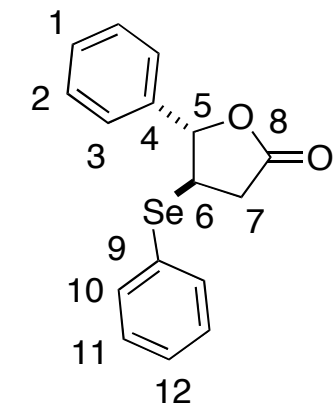

11

A flame-dried, 10-mL, Schlenk flask equipped with a stir bar under an atmosphere of argon was charged with benzeneselenenyl chloride (211 mg, $1.1 \mathrm{mmol}, 1.1$ equiv) and 2,6-di-tert-butyl-4methylpyridine (201 mg, $0.98 \mathrm{mmol}, 0.98$ equiv). $\mathrm{CH}_{2} \mathrm{Cl}_{2}(4 \mathrm{~mL})$ was added via syringe and the resulting solution cooled to $-75^{\circ} \mathrm{C}$ (bath temperature) with an external $i \mathrm{ProH} / \mathrm{CO}_{2}$ cold bath. A solution of 4-phenylbut-3-enoic acid (162 mg, $1.0 \mathrm{mmol}, 1.0$ equiv) in $\mathrm{CH}_{2} \mathrm{Cl}_{2}$ (4 mL) was added dropwise via cannula to the orange suspension; the immediate formation of a homogeneous yellow solution was observed. The reaction mixture was stirred for $2 \mathrm{~h}$ at $-75^{\circ} \mathrm{C}$, the cool bath removed and the mixture stirred for an hour further. The resulting dark-yellow solution was transferred to a $25-\mathrm{mL}$ round bottom-flask with $\mathrm{CH}_{2} \mathrm{Cl}_{2}(3 \times 1 \mathrm{~mL})$ and then was concentrated in vacuo to afford $361 \mathrm{mg}$ of a dark yellow oil. The crude material was pre-adsorbed onto $\mathrm{SiO}_{2}(1$ $\mathrm{g}$ ), and purified by column chromatography $\left(\mathrm{SiO}_{2}, 20 \mathrm{~g}, 20 \mathrm{~mm} \varnothing \times 12 \mathrm{~cm}\right.$, hexanes/Et $2 \mathrm{O}, 9: 1$, $400 \mathrm{~mL}$ ) to afford $301 \mathrm{mg}$ of a pale pink liquid. Bulb-to-bulb distillation afforded $263 \mathrm{mg}(83 \%)$ of $( \pm)-\mathbf{1 1}$ as a colorless liquid.

\section{Data for $( \pm)-\mathbf{1 1}$ :}

bp: $\quad 130{ }^{\circ} \mathrm{C}\left(5 \times 10^{-5} \mathrm{mmHg}, \mathrm{ABT}\right)$

${ }^{1}$ H NMR: $\quad\left(500 \mathrm{MHz}, \mathrm{CDCl}_{3}\right)$

7.52-7.55 (m, $2 \mathrm{H}, \mathrm{CH}(10))$, 7.35-7.39 (m, $4 \mathrm{H}, \mathrm{CH}(1,2,12)$ ), 7.28-7.33 (m, $4 \mathrm{H}$, $\mathrm{CH}(3,11)), 5.38$ (d, $J=6.9 \mathrm{~Hz}, 1 \mathrm{H}, \mathrm{CH}(5)), 3.76$ (ddd, $J=8.3,8.3,6.9 \mathrm{~Hz}, 1 \mathrm{H}$, 
$\mathrm{CH}(6)), 3.04\left(\mathrm{dd}, J=18.1,8.3 \mathrm{~Hz}, 1 \mathrm{H}, \mathrm{CH}_{2}(7 \mathrm{a})\right), 2.68$ (dd, $J=18.1,8.3 \mathrm{~Hz}, 1 \mathrm{H}$, $\left.\mathrm{CH}_{2}(7 \mathrm{~b})\right)$

${ }^{13} \mathrm{C} \mathrm{NMR}: \quad\left(126 \mathrm{MHz}, \mathrm{CDCl}_{3}\right)$

174.5 (C(8)), 137.2 (C(4)), 136.0 (C(10)), 129.5 (C(2)), 128.9, 128.8, 128.7 (C(11), 125.9 (C(9)), 125.7 (C(3)), $86.0(\mathrm{C}(5)), 42.1 \mathrm{C}(6)), 35.8$ (C(7))

${ }^{77}$ Se NMR: $\quad\left(143 \mathrm{MHz}, \mathrm{CDCl}_{3}\right)$

370.90

IR: (neat)

3059 (m), 3034 (m), 2917 (w), 1956 (w), 1885 (w), 1782 (s), 1604 (w), 1577 (m), 1496 (m), 1477 (m), 1456 (m), 1437 (m), 1414 (m), 1371 (w), 1277 (m), 1256 (m), 1217 (s), 1202 (s), 1159 (s), 1138 (s), 1068 (m), 1044 (m), 1021 (m), 999 (m), $912(\mathrm{~m}), 865(\mathrm{~m}), 834(\mathrm{w}), 741(\mathrm{~s}), 696(\mathrm{~s}), 629(\mathrm{~m})$

MS: $\quad(\mathrm{EI}, 70 \mathrm{eV})$

$318\left(49, \mathrm{M}^{+}\right.$), 316 (25), 186 (21), 185 (13), 184 (100), 183 (30), 182 (54), 181 (29), 180 (24), 161 (44), 160 (37), 158 (28), 157 (21), 156 (15), 155, (15), 133 (23), 131 (14), 117 (50), 116 (11), 115 (42), 105 (68), 104 (36), 103 (21), 91 (44), 79 (12), 78 (41), 77 (75), 65 (14)

TLC: $\quad R_{f} 0.12($ hexanes/Et $2 \mathrm{O}, 9: 1)[\mathrm{CAM} / \Delta]$

Preparation of $( \pm)-(4 R S, 5 S R)-D i h y d r o-4-(p h e n y l s e l e n o)-5-(2-m e t h y l p h e n y l) f u r a n-2(3 H)-$ one (24) [MGE-VII-47]

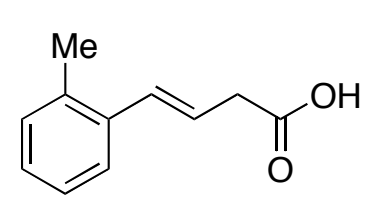

23

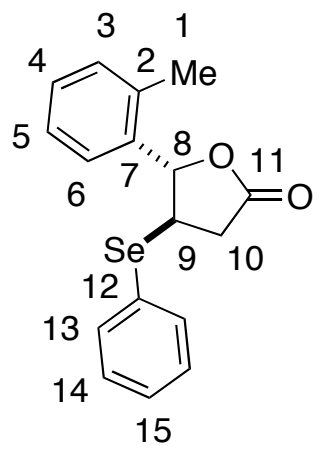

24

A flame-dried, 10-mL, Schlenk flask equipped with a stir bar under an atmosphere of argon was 
charged with benzeneselenenyl chloride (211 mg, $1.1 \mathrm{mmol}, 1.1$ equiv) and 2,6-di-tert-butyl-4methylpyridine (201 $\mathrm{mg}, 0.98 \mathrm{mmol}, 0.98$ equiv). $\mathrm{CH}_{2} \mathrm{Cl}_{2}(4 \mathrm{~mL})$ was added via syringe and the resulting solution cooled to $-75{ }^{\circ} \mathrm{C}$ (bath temperature) with an external $i \mathrm{ProH} / \mathrm{CO}_{2}$ cold bath. A solution of 4-(2-methylphenyl)but-3-enoic acid (176 mg, $1.0 \mathrm{mmol}, 1.0$ equiv) in $\mathrm{CH}_{2} \mathrm{Cl}_{2}(4 \mathrm{~mL})$ was added dropwise via cannula to the orange suspension; the immediate formation of a homogeneous yellow solution was observed. The reaction mixture was stirred for $2 \mathrm{~h}$ at $-75^{\circ} \mathrm{C}$, the cool bath removed and the mixture stirred for an hour further. The resulting dark-yellow solution was transferred to a $25-\mathrm{mL}$ round-bottom flask with $\mathrm{CH}_{2} \mathrm{Cl}_{2}(3 \times 1 \mathrm{~mL})$ and then was concentrated in vacuo to afford $354 \mathrm{mg}$ of a dark yellow oil. The crude material was preadsorbed onto silica gel $(1 \mathrm{~g})$, and purified by column chromatography $\left(\mathrm{SiO}_{2}, 20 \mathrm{~g}, 20 \mathrm{~mm} \varnothing \times\right.$ $12 \mathrm{~cm}$, hexanes/ $\mathrm{Et}_{2} \mathrm{O}, 9: 1,400 \mathrm{~mL}$ ) to afford $291 \mathrm{mg}$ of a pale pink liquid. Bulb-to-bulb distillation afforded $266 \mathrm{mg}(81 \%)$ of $( \pm)-\mathbf{2 4}$ as a viscous, pink liquid.

Data for $( \pm)-24$ :

bp: $\quad 150{ }^{\circ} \mathrm{C}\left(5 \times 10^{-5} \mathrm{mmHg}, \mathrm{ABT}\right)$

${ }^{1}$ H NMR: $\quad\left(500 \mathrm{MHz}, \mathrm{CDCl}_{3}\right)$

7.53-7.56 (m, $2 \mathrm{H}, \mathrm{CH}(13)), 7.36$ (dt, $J=7.3,1.4 \mathrm{~Hz}, 1 \mathrm{H}, \mathrm{CH}(15)), 7.29$ (2H, dt, $J=7.3,1.5 \mathrm{~Hz}, 1 \mathrm{H}, 2 \mathrm{H}, \mathrm{CH}(14)), 7.22-7.25(\mathrm{~m}, 3 \mathrm{H}, \mathrm{CH}(3,4,5)), 7.17$ (d, $J=7.1$ $\mathrm{Hz}, 1 \mathrm{H}, \mathrm{CH}(6)), 5.68$ (d, $J=5.0 \mathrm{~Hz}, 1 \mathrm{H}, \mathrm{CH}(8)), 3.83$ (ddd, $J=8.0,6.0,5.0,1$ H, CH(9)), 3.05 (dd, $J=18.2,8.0 \mathrm{~Hz}, 1 \mathrm{H}, \mathrm{CH}_{2}(10 \mathrm{a}), 2.67$ (dd, J = 18.1, $6.0 \mathrm{~Hz}$, $\mathrm{CH}_{2}(10 \mathrm{~b}), 2.29$ (s, $\left.3 \mathrm{H}, \mathrm{CH}_{3}(1)\right)$

${ }^{13}$ C NMR: $\quad\left(126 \mathrm{MHz}, \mathrm{CDCl}_{3}\right)$

$175.0(\mathrm{C}(11)), 135.9(\mathrm{C}(13)), 135.5(\mathrm{C}(7)), 135.3(\mathrm{C}(2)), 131.0(\mathrm{C}(3)), 129.5$ (C(14)), 129.0 (C(15)), $128.7(\mathrm{C}(4)), 126.4(\mathrm{C}(5)), 126.4$ (C(12)), 124.7 (C(6)), $83.6(\mathrm{C}(8)), 41.1(\mathrm{C}(10)), 35.8(\mathrm{C}(10)), 19.3(\mathrm{C}(1))$

${ }^{77}$ Se NMR: $\quad\left(143 \mathrm{MHz}, \mathrm{CDCl}_{3}\right)$

390.1

IR: (neat)

3056 (m), 3026 (w), 2923 (w), 1782 (s), 1606 (w), 1578 (m), 1477 (m), 1462 (m), 1438 (m), 1412 (m), 1361 (w), 1301 (w), 1254 (m), 1209 (s), 1157 (m), 1110 (m), 1068 (m), 1048 (m), 1021 (m), 999 (s), 977 (m), 866 (m), 837 (m), 742 (s), 692 
MS: $\quad(E I, 70 \mathrm{eV})$

$332\left(\left(\mathrm{M}^{+}, 34\right), 330\right.$ (17), 186 (22), 185 (15), 184 (100), 183 (28), 182 (55), 181

(30), 180 (26), 176 (15), 175 (50), 174 (18), 158 (26), 157 (22), 156 (14), 147

(18), 145 (18), 132 (10), 131 (71), 129 (25), 128 (14), 119 (37), 117 (24), 116

(26), 115 (35), 105 (21), 104 (29), 103 (17), 91 (62), 86 (78), 84 (11), 78 (50), 77

(46), 65 (23), 55 (10)

TLC: $\quad R_{f} 0.14$ (hexanes/Et $\left.2 \mathrm{O}, 9: 1\right)[\mathrm{CAM} / \Delta]$

Analysis: $\quad \mathrm{C}_{17} \mathrm{H}_{16} \mathrm{O}_{2} \mathrm{Se}(331.27)$

Calcd: $\quad$ C, $61.64 ; \quad \mathrm{H}, 4.87 \%$

Found: $\quad$ C, $61.90 ; \quad \mathrm{H}, 4.83 \%$

Preparation of $( \pm)-(4 R S, 5 S R)-4-C h l o r o-4,5-d i h y d r o-5-p h e n y l f u r a n-2(3 H)$-one (27) [MGEVII-86]

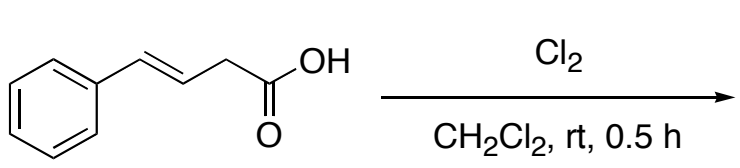

10

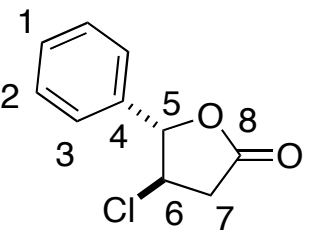

27

A 50-mL, one-neck, round-bottom flask with a magnetic stir bar was charged with 4-phenyl-3butenoic acid (250 mg, $1.54 \mathrm{mmol}, 1.0$ equiv) and $\mathrm{CH}_{2} \mathrm{Cl}_{2}(10 \mathrm{~mL})$ added. The resulting colorless solution was stirred vigorously while chlorine gas was bubbled through the solution until a yellow coloration was observed. The mixture was then allowed to stir at room temperature for $30 \mathrm{~min}$. Upon completion the reaction was diluted with $\mathrm{CH}_{2} \mathrm{Cl}_{2}(25 \mathrm{~mL})$, transferred to a $125-$ $\mathrm{mL}$ separatory funnel and was extracted with saturated aqueous sodium thiosulfate solution $(2 \times$ $25 \mathrm{~mL})$. The organic extract was washed with saturated brine $(50 \mathrm{~mL})$, dried $\left(\mathrm{MgSO}_{4}\right)$, filtered and concentrated in vacuo to afford $613 \mathrm{mg}$ of a yellow oil. The crude material was loaded directly onto silica gel and purified by column chromatography $\left(\mathrm{SiO}_{2}, 50 \mathrm{~g}, 30 \mathrm{~mm} \varnothing \times 9 \mathrm{~cm}\right.$, hexanes/ $\left.\mathrm{Et}_{2} \mathrm{O}, 9: 1,1 \mathrm{~L}\right)$ to afford a pale liquid that was further purified by bulb-to-bulb distillation to afford $177 \mathrm{mg}(58 \%)$ of $( \pm)$-27 as a colorless liquid that solidified as a dense cream solid upon standing. Although the product is obtained in pure form after distillation, some 
material is lost through decomposition in the distillation pot.

Data for $( \pm)-27$ :

bp: $\quad 155^{\circ} \mathrm{C}(0.08 \mathrm{mmHg}, \mathrm{ABT})$

${ }^{1}$ H NMR: $\quad\left(500 \mathrm{MHz}, \mathrm{CDCl}_{3}\right)$

7.39-7.45 (m, $3 \mathrm{H}, \mathrm{CH}(1,2))$, 7.35-7.38 (m, $2 \mathrm{H}, \mathrm{CH}(3)), 5.56(\mathrm{~d}, J=4.6,1 \mathrm{H}$, $\mathrm{CH}(5)$ ), 4.43 (ddd, $J=4.6,5.4,7.3,1 \mathrm{H}, \mathrm{CH}(6)), 3.14$ (dd, $J=18.1,7.3,1 \mathrm{H}$, $\mathrm{CH}_{2}(7 \mathrm{a}), 2.86$ (dd, $\left.J=18.1,5.4,1 \mathrm{H}, \mathrm{CH}_{2}(7 \mathrm{~b})\right)$

${ }^{13}$ C NMR: $\quad\left(126 \mathrm{MHz}, \mathrm{CDCl}_{3}\right)$

$172.7(\mathrm{C}(8)), 135.8(\mathrm{C}(4)), 129.3(\mathrm{C}(1)), 129.0(\mathrm{C}(2)), 125.2(\mathrm{C}(3)), 87.5(\mathrm{C}(5))$, $57.7(\mathrm{C}(6)), 38.1(\mathrm{C}(7))$

IR: (neat)

3066 (m), 3035 (m), 2930 (m), 1790 (s), 1605 (w), 1587 (w), 1497 (m), $1456(\mathrm{~s})$, 1415 (m), 1376 (m), 1357 (m), 1324 (m), 1300 (m), 1266 (s), 1229 (s), 1190 (s), 1143 (s), 1084 (m), 1047 (s), 1030 (m), 998 (s), 963 (m), 942 (s), 870 (s), 842 (m), $799(\mathrm{~m}), 758(\mathrm{~s}), 699(\mathrm{~s}), 632(\mathrm{~m}), 607(\mathrm{~m})$

MS: $\quad(E I, 70 \mathrm{eV})$

$198\left(9, \mathrm{M}^{+}\left[{ }^{37} \mathrm{Cl}\right]\right), 196\left(27, \mathrm{M}^{+}\left[{ }^{35} \mathrm{Cl}\right]\right), 160$ (13), 131 (14), 115 (15), 107 (100), 106 (29), 105 (86), 77 (30), 62 (21)

TLC: $\quad R_{f} 0.13$ (hexanes/Et $\left.{ }_{2} \mathrm{O}, 9: 1\right)[\mathrm{CAM} / \Delta]$

Analysis: $\quad \mathrm{C}_{10} \mathrm{H}_{9} \mathrm{ClO}_{2}(196.63)$

Calcd: $\quad$ C, $61.08 ; \quad \mathrm{H}, 4.61 \%$

Found: $\quad$ C, $61.30 ; \quad \mathrm{H}, 4.46 \%$ 


\subsection{Reaction of carboxylic acid 10 with halogens}

\section{Preparation of ( \pm )-(3RS, 4SR)-3,4-Dibromo-4-phenylbutanoic acid (28) ${ }^{8}$ [MGE-VII-85]}

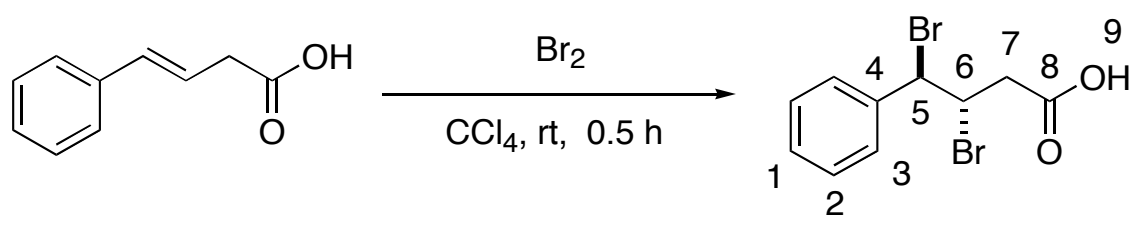

10

28

A $25-\mathrm{mL}$, one-neck, round-bottom flask with a stirrer bar was charged with 4-phenyl-3-butenoic acid 10 (250 mg, $1.54 \mathrm{mmol}, 1.0$ equiv) and $\mathrm{CCl}_{4}(7.5 \mathrm{~mL})$ added. A $15-\mathrm{mL}$ pressure-equalizing dropping funnel was attached and a solution of bromine (258 $\mathrm{mg}, 1.62 \mathrm{mmol}, 1.05$ equiv) in $\mathrm{CCl}_{4}$ added dropwise to the vigorously-stirred solution. Rapid decolorization of bromine was observed upon addition and subsequently a white solid crystallized from solution. The mixture was then allowed to stir at room temperature for $30 \mathrm{~min}$. Upon completion, the reaction was concentrated in vacuo to afford the crude product as a peach colored solid. Pure material was obtained by recrystallization from $\mathrm{CCl}_{4}$. The solid was dissolved in $3 \mathrm{~mL}$ of hot $\mathrm{CCl}_{4}$ and was cooled to $-13{ }^{\circ} \mathrm{C}$ (freezer) to afford colorless micro-cubes of the product. The crystals were filtered cold, washed with chilled $\left(-13{ }^{\circ} \mathrm{C}\right) \mathrm{CCl}_{4}(2 \times 5 \mathrm{~mL})$ and dried under high vacuum $(0.05$ $\mathrm{mm} \mathrm{Hg}$ ) to afford $320 \mathrm{mg}(65 \%)$ of $\mathbf{2 8}$ as colorless micro-cubes.

Data for $( \pm)-\mathbf{2 8}$ :

mp: $\quad 133-134{ }^{\circ} \mathrm{C}\left(\mathrm{CCl}_{4}\right)$

${ }^{1}$ H NMR: $\quad\left(500 \mathrm{MHz}, \mathrm{CDCl}_{3}\right)$

11.60 (br. s, $1 \mathrm{H}, \mathrm{OH}(9))$ ), 7.35-7.44 (m, $5 \mathrm{H}, \mathrm{CH}(1,2,3)$ ), 5.34 (d, $1 \mathrm{H}, J=10.6$ $\mathrm{Hz}, \mathrm{CH}(5)), 4.83$ (ddd, $J=10.5,9.5,3.0 \mathrm{~Hz}, 1 \mathrm{H}, \mathrm{CH}(6)), 3.76$ (dd, $J=17.0,3.0$ $\left.\mathrm{Hz}, \mathrm{CH}_{2}(7 \mathrm{a})\right), 3.16$ (dd, $\left.J=17.0,9.4 \mathrm{~Hz}, \mathrm{CH}_{2}(7 \mathrm{~b})\right)$

${ }^{13}$ C NMR: $\quad\left(126 \mathrm{MHz}, \mathrm{CDCl}_{3}\right)$ $176.0(\mathrm{C}(8)), 139.4(\mathrm{C}(4)), 129.1(\mathrm{C}(1)), 128.8(\mathrm{C}(2)), 127.8(\mathrm{C}(3)), 56.0(\mathrm{C}(5))$, $49.5(\mathrm{C}(6)), 42.9(\mathrm{C}(7))$

IR: $\quad\left(\mathrm{CH}_{2} \mathrm{Cl}_{2}\right)$

3033 (m), 2990 (m), 2908 (br. m), 2685 (m), 2576 (m), 1944 (w), 1707 (s), 1496 (w), $1456(\mathrm{~m}), 1430(\mathrm{~m}), 1407$ (m), $1358(\mathrm{w}), 1312(\mathrm{~s}), 1216(\mathrm{w}), 1185(\mathrm{w}), 1141$ 
(m), 1103 (w), 1084 (w), 1030 (w), 960 (m), 939 (m), 822 (m), 765 (m), 738 (m), $690(\mathrm{~s}), 661(\mathrm{~m})$

MS: $\quad\left(\mathrm{ESI}-, \mathrm{NH}_{4} \mathrm{OH}\right)$

$323\left(50, \mathrm{M}-\mathrm{H}^{+}\left[{ }^{81} \mathrm{Br}_{2}\right]\right), 321\left(100, \mathrm{M}-\mathrm{H}^{+}\left[{ }^{81} \mathrm{Br}{ }^{79} \mathrm{Br}\right]\right), 319\left(50, \mathrm{M}-\mathrm{H}^{+}\left[{ }^{79} \mathrm{Br}_{2}\right]\right)$

\subsection{Reaction of Ester Derivatives of Acid 10 with Benzeneselenenyl Chloride}

General Procedure 2: Reaction of Silyl Esters with Benzeneselenenyl Chloride. Reaction of (E)-Trimethylsilyl 4-Phenyl-3-butenoate 15b with Benzeneselenenyl Chloride [MGE-VII68]

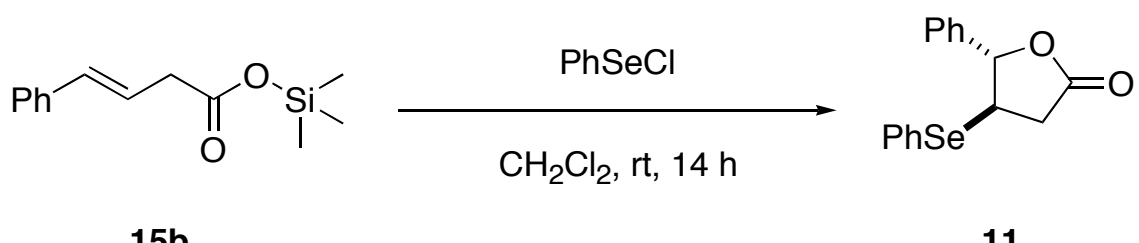

15b

A flame-dried, 10-mL, Schlenk flask equipped with a magnetic stir bar under an atmosphere of argon was charged with benzeneselenenyl chloride $\left(211 \mathrm{mg}, 1.1 \mathrm{mmol}, 1.1\right.$ equiv). $\mathrm{CH}_{2} \mathrm{Cl}_{2}$ (4 $\mathrm{mL}$ ) was added via syringe followed by a solution of $(E)$-trimethylsilyl 4-phenyl-3-butenoate 15b (234 mg, $1.0 \mathrm{mmol}, 1.0$ equiv) in $\mathrm{CH}_{2} \mathrm{Cl}_{2}(1 \mathrm{~mL})$ was added dropwise via cannula to the orange solution. The reaction mixture was stirred for $14 \mathrm{~h}$ at room temperature and the resulting yellow/orange solution was transferred to a $25-\mathrm{mL}$, round-bottom flask with $\mathrm{CH}_{2} \mathrm{Cl}_{2}(3 \times 1 \mathrm{~mL})$. Concentration in vacuo afforded a dark-yellow oil. The extent of conversion was determined by recording the ${ }^{1} \mathrm{H}$ NMR of the crude mixture in $\mathrm{CDCl}_{3}$ and a liquid film IR was obtained by spotting the crude material on $\mathrm{NaCl}$ plates. The crude material was then pre-adsorbed onto silica gel (2 g), and purified by column chromatography $\left(\mathrm{SiO}_{2}, 20 \mathrm{~g}, 20 \mathrm{~mm} \varnothing \times 12 \mathrm{~cm}\right.$, hexanes/Et ${ }_{2} \mathrm{O}$, 9:1, $400 \mathrm{~mL})$ to afford $243 \mathrm{mg}(77 \%)$ of $( \pm)-\mathbf{1 1}$ as a pale pink liquid.

Data from crude mixture:

IR: (neat, selected signals)

1787 (s) 
Reaction of $(E)$-Triethylsilyl 4-Phenyl-3-butenoate 15c with Benzeneselenenyl Chloride [MGE-VII-73]

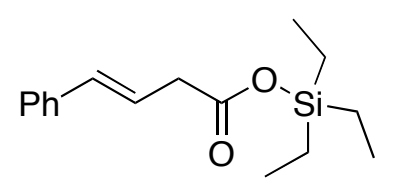

$15 c$

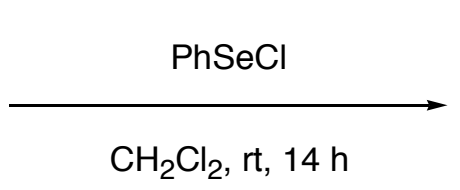

$\mathrm{CH}_{2} \mathrm{Cl}_{2}, \mathrm{rt}, 14 \mathrm{~h}$

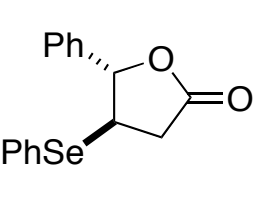

11

Following General Procedure 2, with benzeneselenenyl chloride (211 mg, $1.1 \mathrm{mmol}, 1.1$ equiv) and (E)-triethylsilyl 4-phenyl-3-butenoate $15 \mathrm{c}(276 \mathrm{mg}, 1.0 \mathrm{mmol}, 1.0$ equiv) afforded $228 \mathrm{mg}$ $(72 \%)$ of $( \pm)-11$ as a pale pink liquid.

Data from crude mixture:

IR: $\quad$ (neat, selected signals)

$1787(\mathrm{~s})$

\section{Reaction of (E)-tert-Butyldimethylsilyl 4-Phenyl-3-butenoate 15d with Benzeneselenenyl Chloride [MGE-VII-64]}

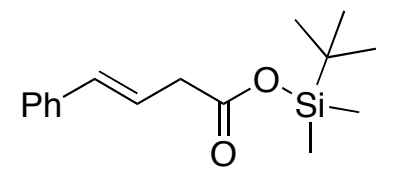

15d

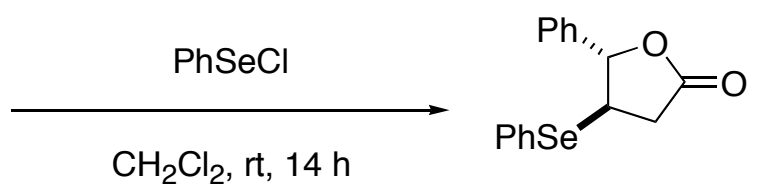

11

Following General Procedure 2, with benzeneselenenyl chloride (211 mg, $1.1 \mathrm{mmol}, 1.1$ equiv) and (E)-tert-butyldimethylsilyl 4-phenyl-3-butenoate 15d (276 mg, $1.0 \mathrm{mmol}, 1.0$ equiv) afforded $230 \mathrm{mg}(73 \%)$ of $( \pm)-11$ as a pale pink liquid.

Data from crude mixture:

IR: $\quad$ (neat, selected signals)

$1787(\mathrm{~s}), 1719$ (s) 
Reaction of (E)-Triisopropylsilyl 4-Phenyl-3-butenoate 15e with Benzeneselenenyl Chloride [MGE-VII-65]

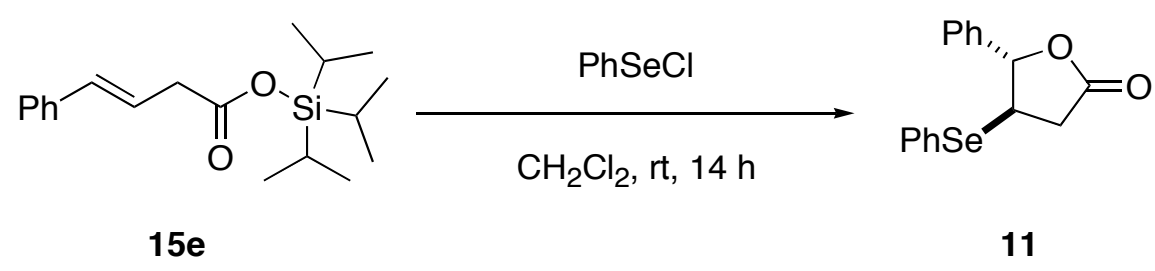

Following General Procedure 2, with benzeneselenenyl chloride (211 mg, $1.1 \mathrm{mmol}, 1.1$ equiv) and (E)-triisopropylsilyl 4-phenyl-3-butenoate $\mathbf{1 5 e}(318 \mathrm{mg}, 1.0 \mathrm{mmol}, 1.0$ equiv) afforded 206 $\mathrm{mg}(65 \%)$ of $( \pm)-\mathbf{1 1}$ as a pale pink liquid.

Data from crude mixture:

IR: $\quad$ (neat, selected signals)

1787 (s), 1719 (s)

Reaction of (E)-tert-Butyldiphenylsilyl 4-Phenyl-3-butenoate 15f with Benzeneselenenyl Chloride [MGE-VII-69]

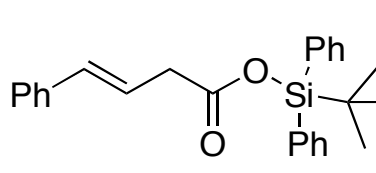

$15 f$

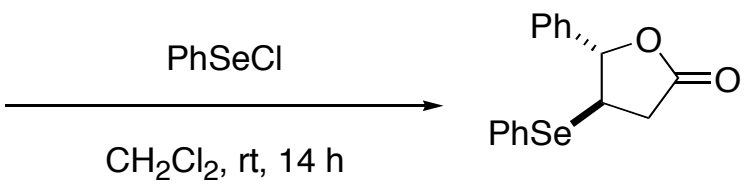

11

Following General Procedure 2, with benzeneselenenyl chloride (211 mg, $1.1 \mathrm{mmol}, 1.1$ equiv) and (E)-tert-butyldiphenylsilyl 4-phenyl-3-butenoate $\mathbf{1 5 f}$ (400 $\mathrm{mg}, 1.0 \mathrm{mmol}, 1.0$ equiv) afforded $153 \mathrm{mg}(48 \%)$ of $( \pm)-\mathbf{1 1}$ as a pale pink liquid.

Data from crude mixture:

IR: (neat, selected signals)

$1787(\mathrm{~m}), 1719(\mathrm{~s})$ 


\section{General Procedure 3. React-IR in situ Spectroscopic Monitoring of Reactions Between Silyl Esters and Benzeneselenenyl Chloride.}

An oven-dried, 3-neck, React-IR cell containing a stir bar was connected to the React-IR probe (vide infra) and fitted with an argon-inlet adaptor. The apparatus was cooled under a stream of argon and then maintained under a static atmosphere of argon pressure. The cell was charged with benzeneselenenyl chloride (53 mg, $0.276 \mathrm{mmol}, 1.1$ equiv) and $\mathrm{CH}_{2} \mathrm{Cl}_{2}(2 \mathrm{~mL})$ and the resulting orange solution stirred at ambient temperature while the background was scanned. Scanning was then commenced (1500-2000 cm-1 range, $16 \mathrm{~cm}^{-1}$ resolution, 64 scans per minute) and after a three-minute delay a solution of the required silyl ester $(0.25 \mathrm{mmol}, 1.0$ equiv $)$ in 0.5 $\mathrm{mL}$ of $\mathrm{CH}_{2} \mathrm{Cl}_{2}$ was added rapidly via syringe. The reaction was monitored by observing disappearance of the silyl ester carbonyl signal (vide supra) and appearance of the carbonyl signal of lactone $\mathbf{1 1}$ at $1783 \mathrm{~cm}^{-1}$.

\section{Reaction of (E)-Methyl 4-Phenyl-3-butenoate 15g with Benzeneselenenyl Chloride [MGE- VII-74]}<smiles>COC(=O)C/C=C/c1ccccc1</smiles>

$15 \mathrm{~g}$

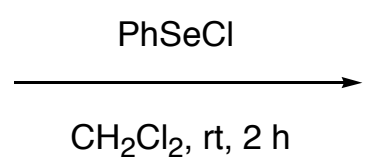

$\mathrm{CH}_{2} \mathrm{Cl}_{2}, \mathrm{rt}, 2 \mathrm{~h}$

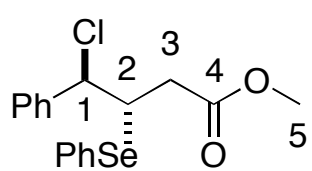

$16 \mathrm{~g}$

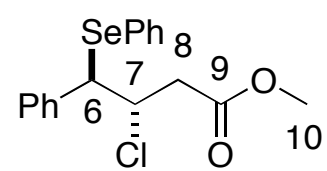

$17 g$

A flame-dried, 10-mL, Schlenk flask equipped with a stir bar under an atmosphere of argon was charged with benzeneselenenyl chloride $\left(211 \mathrm{mg}, 1.1 \mathrm{mmol}, 1.1\right.$ equiv). $\mathrm{CH}_{2} \mathrm{Cl}_{2}$ (4 mL) was added via syringe followed by a solution of (E)-methyl 4-phenyl-3-butenoate 15g (176 mg, 1.0 mmol, 1.0 equiv) in $\mathrm{CH}_{2} \mathrm{Cl}_{2}(1 \mathrm{~mL})$ was added dropwise via cannula to the orange solution. The reaction mixture was stirred for $2 \mathrm{~h}$ at room temperature and the resulting yellow/orange solution was transferred to a $25-\mathrm{mL}$, round-bottom flask with $\mathrm{CH}_{2} \mathrm{Cl}_{2}(3 \times 1 \mathrm{~mL})$ concentration in vacuo afforded a dark yellow oil. ${ }^{1} \mathrm{H}$ NMR analysis of the crude mixture in $\mathrm{CDCl}_{3}$ indicated $92 \%$ conversion of $\mathbf{1 5 g}$ into a mixture of $\mathbf{1 6 g}(52 \%)$ and $\mathbf{1 7 g}(40 \%)$. Attempts to purify this material by either chromatography or distillation resulted only in cyclization to selenolactone $\mathbf{1 1}$. 


\section{Data for 16g [52\%]:}

${ }^{1} \mathrm{H} \mathrm{NMR}: \quad\left(500 \mathrm{MHz}, \mathrm{CDCl}_{3}\right.$, selected signals)

5.15 (d, $1 \mathrm{H}, J=9.9 \mathrm{~Hz}, \mathrm{CH}(1)), 3.94$ (ddd, $J=9.7,8.9,4.1 \mathrm{~Hz}, \mathrm{CH}(2)), 3.73$ (s, 3

$\left.\mathrm{H}, \mathrm{CH}_{3}(5)\right), 3.34(\mathrm{dd}, J=16.8,4.1 \mathrm{~Hz}, 1 \mathrm{H}, \mathrm{CH}(3 \mathrm{a})), 2.94(\mathrm{dd}, 1 \mathrm{H}, J=16.7,9.0$ $\mathrm{Hz}, \mathrm{CH}(3 \mathrm{~b}))$

${ }^{13} \mathrm{C}$ NMR: $\quad\left(126 \mathrm{MHz}, \mathrm{CDCl}_{3}\right.$, selected signals)

$171.6(\mathrm{C}(4)), 66.6(\mathrm{C}(1)), 47.2(\mathrm{C}(2)), 38.4(\mathrm{C}(3))$,

${ }^{77} \mathrm{Se} N M R: \quad\left(143 \mathrm{MHz}, \mathrm{CDCl}_{3}\right)$

401.2

Data for $17 \mathrm{~g}$ [40\%]:

${ }^{1} \mathrm{H}$ NMR: $\quad\left(500 \mathrm{MHz}, \mathrm{CDCl}_{3}\right.$, selected signals)

4.87 (ddd, $J=9.1,9.2,3.8 \mathrm{~Hz}, 1 \mathrm{H}, \mathrm{CH}(7)), 4.49$ (d, $J=9.1 \mathrm{~Hz}, \mathrm{CH}(6)), 3.73$ (3

$\left.\mathrm{H}, \mathrm{s}, \mathrm{CH}_{3}(10)\right), 3.35$ (dd, $\left.J=16.2,3.8 \mathrm{~Hz}, \mathrm{CH}(8 \mathrm{a})\right), 2.79$ (dd, $J=16.2,9.2 \mathrm{~Hz}$, $\mathrm{CH}(8 \mathrm{~b}))$

${ }^{13} \mathrm{C}$ NMR: $\quad\left(126 \mathrm{MHz}, \mathrm{CDCl}_{3}\right.$, selected signals)

170.4 (C(9)), 60.0 (C(7)), 53.4 (C(6)), 42.4 (C(8))

${ }^{77}$ Se NMR: $\quad\left(143 \mathrm{MHz}, \mathrm{CDCl}_{3}\right)$

460.3

Data for $\mathbf{1 6 g} / \mathbf{1 7 g}$ :

IR: $\quad$ (neat, selected signals)

1738 (s)

MS: $\quad$ (EI, $70 \mathrm{eV}$, selected peaks)

$368\left(2, \mathrm{M}^{+}\left[{ }^{80} \mathrm{Se}\right]\right)$

HRMS: $\quad \mathrm{C}_{17} \mathrm{H}_{17}{ }^{35} \mathrm{ClO}_{2}{ }^{80} \mathrm{Se}$

Calcd: $\quad 368.0082$

Found: $\quad 368.0073$ 


\section{Reaction of (E)-Neopentyl 4-Phenyl-3-butenoate $15 \mathrm{~h}$ with Benzeneselenenyl Chloride [MGE-VII-83]}

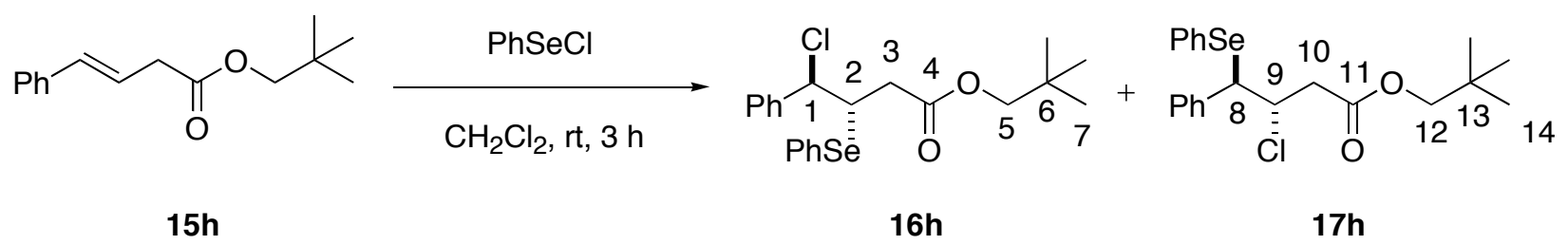

A flame-dried, 10-mL, Schlenk flask equipped with a magnetic stir bar under an atmosphere of argon was charged with benzeneselenenyl chloride (211 mg, $1.1 \mathrm{mmol}, 1.1$ equiv). $\mathrm{CH}_{2} \mathrm{Cl}_{2}$ (4 $\mathrm{mL}$ ) was added via syringe followed by a solution of $(E)$-neopentyl 4-phenyl-3-butenoate $\mathbf{1 5 h}$ (232 mg, $1.0 \mathrm{mmol}, 1.0$ equiv) in $\mathrm{CH}_{2} \mathrm{Cl}_{2}(1 \mathrm{~mL})$ was added dropwise via cannula to the orange solution. The reaction mixture was stirred for $14 \mathrm{~h}$ at room temperature and the resulting yellow/orange solution was transferred to a $25-\mathrm{mL}$, round-bottom flask with $\mathrm{CH}_{2} \mathrm{Cl}_{2}(3 \times 1 \mathrm{~mL})$ concentration in vacuo afforded a dark yellow oil. ${ }^{1} \mathrm{H}$ NMR analysis of the crude mixture in $\mathrm{CDCl}_{3}$ indicated $72 \%$ conversion of $\mathbf{1 5 h}$ into a mixture of $\mathbf{1 6 h}(32 \%)$ and $\mathbf{1 7 h}(40 \%)$. Attempts to purify this material by either chromatography or distillation resulted only in cyclization to selenolactone 11.

Data for $16 \mathrm{~h} \mathrm{[32 \% ]:}$

${ }^{1} \mathrm{H}$ NMR: $\quad\left(500 \mathrm{MHz}, \mathrm{CDCl}_{3}\right.$, selected signals)

5.15 (d, $1 \mathrm{H}, J=9.9 \mathrm{~Hz}, \mathrm{CH}(1)$ ), 3.92 (ddd, $J=9.8,8.7,4.1 \mathrm{~Hz}, \mathrm{CH}(2)), 3.83$ (s, 2 H, $\left.\mathrm{CH}_{2}(5)\right), 3.33$ (dd, $J=16.7,3.9 \mathrm{~Hz}, 1 \mathrm{H}, \mathrm{CH}(3 \mathrm{a})$ ), 2.97 (dd, $1 \mathrm{H}, J=16.7,8.6$ $\mathrm{Hz}, \mathrm{CH}(3 \mathrm{~b})), 0.98$ (s, $\left.9 \mathrm{H}, \mathrm{CH}_{3}(7)\right)$

${ }^{13} \mathrm{C} \mathrm{NMR}: \quad\left(126 \mathrm{MHz}, \mathrm{CDCl}_{3}\right.$, selected signals) $171.3(\mathrm{C}(4)), 66.5(\mathrm{C}(1)), 47.3(\mathrm{C}(2)), 38.6(\mathrm{C}(3))$,

${ }^{77}$ Se NMR: $\quad\left(143 \mathrm{MHz}, \mathrm{CDCl}_{3}\right)$

401.0

Data for 17h [40\%]:

${ }^{1} \mathrm{H}$ NMR: $\quad\left(500 \mathrm{MHz}, \mathrm{CDCl}_{3}\right.$, selected signals)

4.84 (ddd, $J=9.0,4.0,4.0 \mathrm{~Hz}, 1 \mathrm{H}, \mathrm{CH}(9)), 4.49$ (d, $J=8.8 \mathrm{~Hz}, \mathrm{CH}(8)$ ), 3.84 (2 H, s, $\left.\mathrm{CH}_{2}(12)\right), 3.33$ (dd, $J=16.2,3.8 \mathrm{~Hz}, 1 \mathrm{H}, \mathrm{CH}(10 \mathrm{a})$ ), 2.79 (dd, $J=16.1,9.1$ 
$\mathrm{Hz}, \mathrm{CH}(10 \mathrm{~b})), 0.95$ (s, $\left.9 \mathrm{H}, \mathrm{CH}_{3}(14)\right)$

${ }^{13} \mathrm{C} \mathrm{NMR}: \quad\left(126 \mathrm{MHz}, \mathrm{CDCl}_{3}\right.$, selected signals)

169.9 (C(11)), 56.0 (C(9)), 53.3 (C(8)), 42.6 (C(10))

${ }^{77}$ Se NMR: $\quad\left(143 \mathrm{MHz}, \mathrm{CDCl}_{3}\right)$

460.6

Data for $16 \mathrm{~h} / \mathbf{1 7 h}$ :

IR: $\quad$ (neat, selected signals)

$1732(\mathrm{~s})$

MS: $\quad(E I, 70 \mathrm{eV}$, selected peaks)

$424\left(5, \mathrm{M}^{+}\left[{ }^{80} \mathrm{Se}\right]\right)$

HRMS: $\quad \mathrm{C}_{21} \mathrm{H}_{25}{ }^{35} \mathrm{ClO}_{2}{ }^{78} \mathrm{Se}$

Calcd: $\quad 422.0716$

Found: $\quad 422.0714$

\subsection{VT-NMR experiments}

\section{VT-NMR Experiment Between 4-Phenyl-3-butenoic acid 10 and Benzeneselenenyl Chloride in the Presence of DTBMP}

An oven-dried NMR tube was cooled in a dessicator, charged with benzeneselenenyl chloride (35.8 mg, $0.187 \mathrm{mmol}, 1.1$ equiv) and DTBMP (37.6 mg, $0.183 \mathrm{mmol}, 0.98$ equiv) and then was capped with a rubber septum and attached to a vacuum manifold via an inlet needle. The tube was purged three times with a vacuum/argon cycle and then maintained under an atmosphere of argon. $\mathrm{CD}_{2} \mathrm{Cl}_{2}(0.5 \mathrm{~mL})$ was added via syringe and the tube was vortexed for $15 \mathrm{sec}$ to afford an orange/brown solution. The tube was immersed in a $-75{ }^{\circ} \mathrm{C}$ cold bath (bath temperature, acetone $/ \mathrm{CO}_{2}$ ) which resulted in precipitation of the majority of the benzeneselenenyl chloride. A solution of 4-phenyl-3-butenoic acid 10 (13.8 $\mathrm{mg}, 0.085 \mathrm{mmol})$ in $\mathrm{CD}_{2} \mathrm{Cl}_{2}(0.25 \mathrm{~mL})$ was added via cannula and the tube momentarily removed from the cool-bath and was re-vortexed to afford a homogeneous dark-yellow solution. The tube was taken to the pre-cooled $\left(-70{ }^{\circ} \mathrm{C}\right) \mathrm{NMR}$ magnet and inserted. The mixture was aged $30 \mathrm{~min}$ at $-70{ }^{\circ} \mathrm{C}$ and then the ${ }^{1} \mathrm{H}$ NMR spectrum 
was recorded. The temperature was then increased to $-20^{\circ} \mathrm{C}$ and following 30 min more aging the ${ }^{1} \mathrm{H}$ NMR spectrum was recorded. This process was repeated at $0{ }^{\circ} \mathrm{C}$ and then the tube was removed from the NMR spectrometer and allowed to stand at room temperature for $12 \mathrm{~h}$. Then, a final ${ }^{1} \mathrm{H}$ NMR spectrum was recorded.

\section{VT-NMR Experiment Between 4-Phenyl-3-butenoic Acid 10 and Benzeneselenenyl Chloride [MGE-VII-82] ${ }^{10}$}

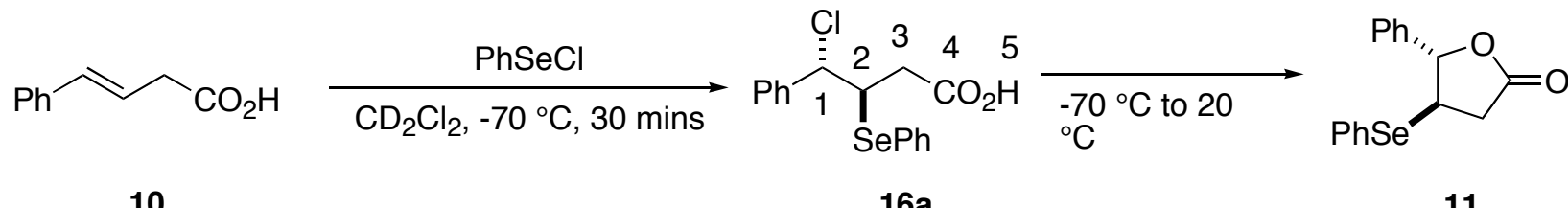

10

$16 a$

11

An oven-dried NMR tube was cooled in a dessicator and then charged with benzeneselenenyl chloride (17.9 mg, $0.0935 \mathrm{mmol}, 1.1$ equiv), then was capped with a rubber septum and attached to a vacuum manifold via an inlet needle. The tube was purged three times with a vacuum/argon cycle and then maintained under an atmosphere of argon. $\mathrm{CD}_{2} \mathrm{Cl}_{2}(0.5 \mathrm{~mL})$ was added via syringe and the tube was vortexed for $15 \mathrm{sec}$ to afford an orange/brown solution. The tube was immersed in a $-75^{\circ} \mathrm{C}$ cold bath (bath temperature, acetone $/ \mathrm{CO}_{2}$ ) which resulted in precipitation of the majority of the benzeneselenenyl chloride. A solution of 4-phenyl-3-butenoic acid 10 (13.8 $\mathrm{mg}, 0.085 \mathrm{mmol})$ in $\mathrm{CD}_{2} \mathrm{Cl}_{2}(0.25 \mathrm{~mL})$ was added via cannula and the tube momentarily removed from the cool-bath and was re-vortexed to afford a homogeneous dark-yellow solution. The tube was taken to the pre-cooled $\left(-70^{\circ} \mathrm{C}\right) \mathrm{NMR}$ magnet and inserted. The mixture was aged for 30 min at $-70{ }^{\circ} \mathrm{C}$ and then both the ${ }^{1} \mathrm{H}$ NMR (64 scans) and ${ }^{13} \mathrm{C}$ NMR (1024 scans) spectra were recorded. The temperature was then increased to $-20^{\circ} \mathrm{C}$ and following 30 min more aging the ${ }^{1} \mathrm{H}$ NMR spectrum (64 scans), was recorded. This process was repeated at $0{ }^{\circ} \mathrm{C}$ and then the tube was removed from the NMR spectrometer and allowed to stand at room temperature for 12 h. Then, a final ${ }^{1} \mathrm{H}$ NMR spectrum was recorded. Under these conditions, the data recorded in Table 3 was obtained.

\section{Data for 16a:}

${ }^{1} \mathrm{H}$ NMR: $\quad\left(500 \mathrm{MHz}, \mathrm{CD}_{2} \mathrm{Cl}_{2},-70{ }^{\circ} \mathrm{C}\right.$, selected signals)

13.11 (br s, $1 \mathrm{H}, \mathrm{OH}(5)$ ), 5.02 (d, $1 \mathrm{H}, J=11.4 \mathrm{~Hz}, \mathrm{CH}(1)$ ), 3.87 (ddd, $J=11.4$, 
10.3, 3.1 Hz, $\mathrm{CH}(2)), 3.60\left(\mathrm{dd}, J=17.2,2.9 \mathrm{~Hz}, 1 \mathrm{H}, \mathrm{CH}_{2}(3 \mathrm{a})\right), 2.92(\mathrm{dd}, 1 \mathrm{H}, J=$ $16.1,10.3 \mathrm{~Hz}, \mathrm{CH}(3 \mathrm{~b}))$

${ }^{13} \mathrm{C}$ NMR: $\quad\left(126 \mathrm{MHz}, \mathrm{CD}_{2} \mathrm{Cl}_{2},-70{ }^{\circ} \mathrm{C}\right.$, selected signals)

$178.8(\mathrm{C}(4)), 65.7(\mathrm{C}(1)), 45.3(\mathrm{C}(2)), 38.2(\mathrm{C}(3))$

\section{General Procedure 4. VT-NMR Experiment Between (E)-Trimethylsilyl 4-Phenyl-3- butenoate 15b and Benzeneselenenyl Chloride [MGE-VII-70]}

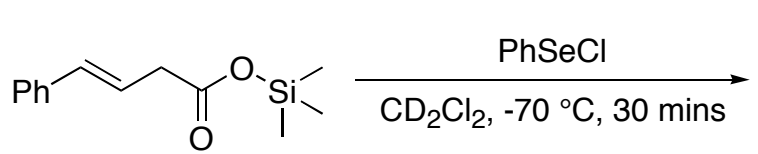

15b

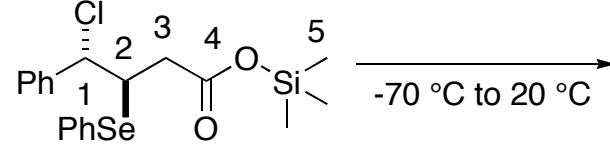

$16 b$

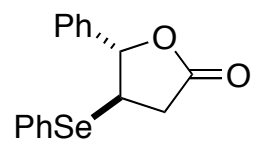

11

An oven-dried, NMR tube was cooled in a dessicator and then charged with benzeneselenenyl chloride (35.8 $\mathrm{mg}, 0.187 \mathrm{mmol}, 1.1$ equiv), capped with a rubber septum and then was attached to a vacuum manifold via an inlet needle. The tube was purged three times with a vacuum/argon cycle and then was maintained under an atmosphere of argon. $\mathrm{CD}_{2} \mathrm{Cl}_{2}(0.5 \mathrm{~mL})$ was added via syringe and the tube was vortexed for $15 \mathrm{sec}$ to afford an orange/brown solution. The tube was immersed in a $-75^{\circ} \mathrm{C}$ cold bath (bath temperature, acetone $/ \mathrm{CO}_{2}$ ) which resulted in precipitation of the majority of the benzeneselenenyl chloride. A solution of $(E)$-trimethylsilyl 4-phenyl 3butenoic acid $15 \mathrm{~b}(39.8 \mathrm{mg}, 0.17 \mathrm{mmol})$ in $\mathrm{CD}_{2} \mathrm{Cl}_{2}(0.25 \mathrm{~mL})$ was added via cannula and the tube momentarily removed from the cool-bath and was re-vortexed to afford a homogeneous dark- yellow solution. The tube was taken to the pre-cooled $\left(-70^{\circ} \mathrm{C}\right) \mathrm{NMR}$ magnet and inserted. The mixture was aged for $30 \mathrm{~min}$ at $-70{ }^{\circ} \mathrm{C}$ and then both the ${ }^{1} \mathrm{H}$ NMR (64 scans) and ${ }^{13} \mathrm{C}$ NMR (1024 scans) spectra were recorded. The temperature was then increased to $-20^{\circ} \mathrm{C}$ and following 30 min more aging the ${ }^{1} \mathrm{H}$ NMR (64 scans) spectrum was recorded. This process was repeated at $0{ }^{\circ} \mathrm{C}$ and then the tube was removed from the NMR spectrometer and was allowed to stand at room temperature for $12 \mathrm{~h}$. Then, a final ${ }^{1} \mathrm{H}$ NMR spectrum was recorded. Under these conditions, the data recorded in Table 4 was obtained.

Data for 16b:

${ }^{1} \mathrm{H}$ NMR: $\quad\left(500 \mathrm{MHz}, \mathrm{CD}_{2} \mathrm{Cl}_{2},-70{ }^{\circ} \mathrm{C}\right.$, selected signals $)$

$5.03(\mathrm{~d}, 1 \mathrm{H}, J=11.4 \mathrm{~Hz}, \mathrm{CH}(1)$ ), 3.81 (ddd, $J=11.2,10.1,3.3 \mathrm{~Hz}, \mathrm{CH}(2)), 3.46$ 
(dd, $\left.J=17.1,3.3 \mathrm{~Hz}, 1 \mathrm{H}, \mathrm{CH}_{2}(3 \mathrm{a})\right), 2.82$ (dd, $J=17.1,9.8 \mathrm{~Hz}, 1 \mathrm{H}, \mathrm{CH}(3 \mathrm{~b})$ ), $0.32\left(\mathrm{~s}, 9 \mathrm{H}, \mathrm{CH}_{3}(5)\right)$

${ }^{13} \mathrm{C}$ NMR: $\quad\left(126 \mathrm{MHz}, \mathrm{CD}_{2} \mathrm{Cl}_{2},-70{ }^{\circ} \mathrm{C}\right.$, selected signals)

$171.6(\mathrm{C}(4)), 66.1(\mathrm{C}(1)), 46.6(\mathrm{C}(2)), 39.7(\mathrm{C}(3)),-0.9(\mathrm{C}(5))$

VT-NMR Experiment Between (E)-Triisopropylsilyl 4-Phenyl-3-butenoate 15e and Benzeneselenenyl Chloride [MGE-VII-71]

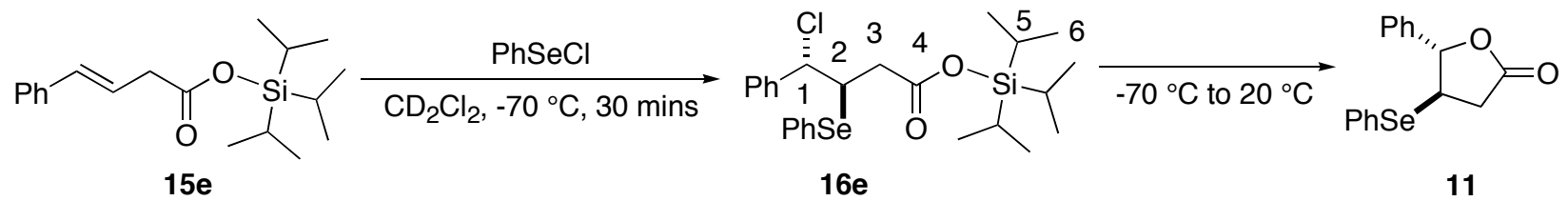

Following General Procedure 4 with benzeneselenenyl chloride (35.8 mg, 0.187 mmol, 1.1 equiv) and (E)-triisopropylsilyl 4-phenyl-3-butenoic acid 15e (54.2 $\mathrm{mg}, 0.17 \mathrm{mmol})$, the data recorded in Table 5 was obtained.

Data for 16e:

${ }^{1} \mathrm{H} \mathrm{NMR}: \quad\left(500 \mathrm{MHz}, \mathrm{CD}_{2} \mathrm{Cl}_{2},-70^{\circ} \mathrm{C}\right.$, selected signals)

$5.06(\mathrm{~d}, J=11.5 \mathrm{~Hz}, 1 \mathrm{H}, \mathrm{CH}(1)), 3.81$ (ddd, $J=11.6,9.3,3.1 \mathrm{~Hz}, 1 \mathrm{H}, \mathrm{CH}(2))$,

$3.50(\mathrm{dd}, J=17.3,3.0 \mathrm{~Hz}, 1 \mathrm{H}, \mathrm{CH}(3 \mathrm{a})), 2.97$ (dd, $J=17.0,9.2 \mathrm{~Hz}, 1 \mathrm{H}, \mathrm{CH}(3 \mathrm{~b}))$,

1.33 (septet, $J=7.4 \mathrm{~Hz}, 3 \mathrm{H}, \mathrm{CH}(5)$ ), 1.09 (dd, $J=7.4,2.9 \mathrm{~Hz}, 18 \mathrm{H}, \mathrm{CH}(6)$

${ }^{13} \mathrm{C}$ NMR: $\quad\left(126 \mathrm{MHz}, \mathrm{CD}_{2} \mathrm{Cl}_{2},-70{ }^{\circ} \mathrm{C}\right.$, selected signals)

171.5 (C(4)), 65.9 (C(1)), 46.4 (C(2)), 39.4 (C(3)), $17.4(\mathrm{C}(6)), 11.4(\mathrm{C}(5))$ 
VT-NMR Experiment Between (E)-Methyl 4-Phenyl-3-butenoate 15g and Benzeneselenenyl Chloride [MGE-VII-76]

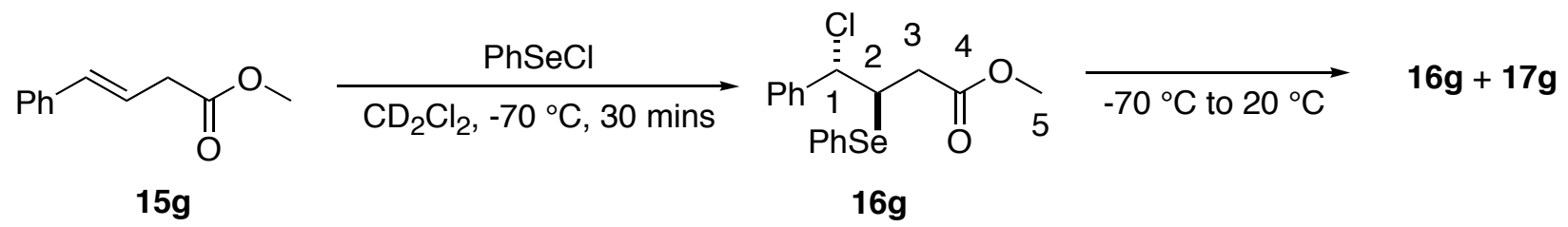

Following General Procedure 4 with benzeneselenenyl chloride $(35.8 \mathrm{mg}, 0.187 \mathrm{mmol}, 1.1$ equiv) and (E)-triisopropylsilyl 4-phenyl-3-butenoic acid $15 \mathrm{~g}(30.0 \mathrm{mg}, 0.17 \mathrm{mmol})$, the data recorded in Table 6 was obtained.

Data for 16g:

${ }^{1}$ H NMR: $\quad\left(500 \mathrm{MHz}, \mathrm{CD}_{2} \mathrm{Cl}_{2},-70{ }^{\circ} \mathrm{C}\right.$, selected signals)

5.02 (d, $J=11.2 \mathrm{~Hz}, 1 \mathrm{H}, \mathrm{CH}(1)), 3.87$ (ddd, $J=11.2,10.4,2.6 \mathrm{~Hz}, \mathrm{CH}(2)), 3.54$

(s, $\left.3 \mathrm{H}, \mathrm{CH}_{3}(5)\right), 3.46\left(\mathrm{dd}, J=16.9,2.8 \mathrm{~Hz}, 1 \mathrm{H}, \mathrm{CH}_{2}(3 \mathrm{a})\right.$ ), 2.97 (dd, $J=16.9$, $\left.10.2 \mathrm{~Hz}, 1 \mathrm{H}, \mathrm{CH}_{2}(3 \mathrm{~b})\right)$

${ }^{13} \mathrm{C}$ NMR: $\quad\left(126 \mathrm{MHz}, \mathrm{CD}_{2} \mathrm{Cl}_{2},-70{ }^{\circ} \mathrm{C}\right.$, selected signals)

$171.7(\mathrm{C}(4)), 66.0(\mathrm{C}(1)), 52.2(\mathrm{C}(5)), 46.2(\mathrm{C}(2)), 37.9(\mathrm{C}(3))$

VT-NMR Experiment Between (E)-4-Phenyl 3-Butenoic Acid 10 and Benzeneselenenyl Bromide [MGE-VII-75]

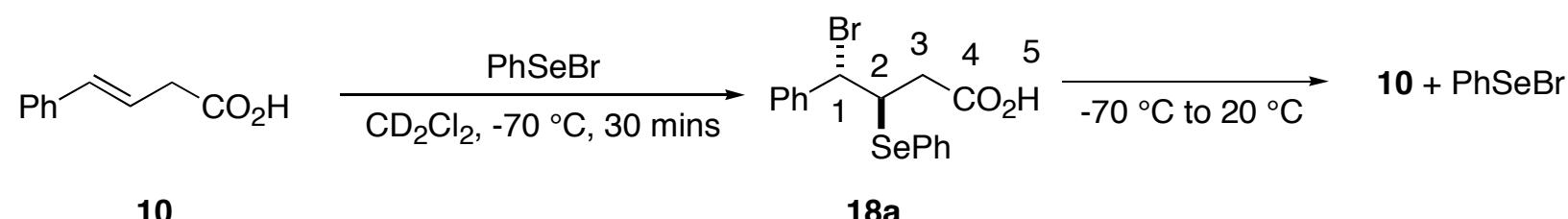

Following General Procedure 4 with benzeneselenenyl bromide $(44.1 \mathrm{mg}, 0.187 \mathrm{mmol}, 1.1$ equiv) and (E)-4-phenyl-3-butenoic acid $10(27.6 \mathrm{mg}, 0.17 \mathrm{mmol}, 1.0$ equiv), the data recorded in Table 7 was obtained. 


\section{Data for 18a:}

${ }^{1} \mathrm{H}$ NMR: $\quad\left(500 \mathrm{MHz}, \mathrm{CD}_{2} \mathrm{Cl}_{2},-50{ }^{\circ} \mathrm{C} \text {, selected signals }\right)^{11}$

12.94 (br. s, $1 \mathrm{H}, \mathrm{OH}(5)), 5.13$ (d, $1 \mathrm{H}, J=12.1 \mathrm{~Hz}, \mathrm{CH}(1)$ ), 4.03 (ddd, $J=12.1$, 10.4, 3.0 Hz, CH(2)), 3.74 (dd, $J=17.3,3.0 \mathrm{~Hz}, 1 \mathrm{H}, \mathrm{CH}_{2}(3 \mathrm{a})$ ), 2.94 (dd, $1 \mathrm{H}, J=$ 17.3, $\left.10.3 \mathrm{~Hz}, \mathrm{CH}_{2}(3 \mathrm{~b})\right)$

${ }^{13} \mathrm{C}$ NMR: $\quad\left(126 \mathrm{MHz}, \mathrm{CD}_{2} \mathrm{Cl}_{2},-70{ }^{\circ} \mathrm{C}\right.$, selected signals)

$178.6(\mathrm{C}(4)), 58.4(\mathrm{C}(1)), 45.0(\mathrm{C}(2)), 39.9(\mathrm{C}(3))$

VT-NMR Experiment Between (E)-4-(2-Methylphenyl) 3-Butenoic Acid 23 and Benzeneselenenyl Chloride [MGE-VII-67]

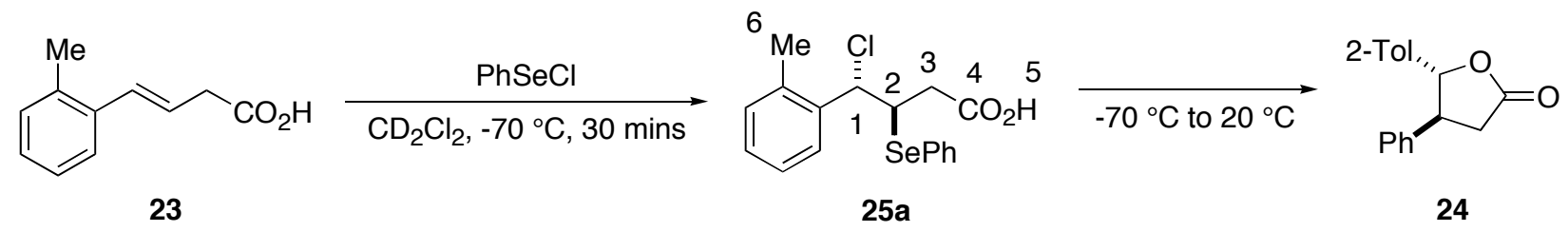

Following General Procedure 4 with benzeneselenenyl chloride (35.8 mg, 0.187 mmol, 1.1 equiv) and (E)-4-(2-methylphenyl) 3-butenoic acid 23 (30.0 mg, $0.17 \mathrm{mmol})$, the data recorded in Table 7 was obtained.

Data for 25a:

${ }^{1} \mathrm{H}$ NMR: $\quad\left(500 \mathrm{MHz}, \mathrm{CD}_{2} \mathrm{Cl}_{2},-70{ }^{\circ} \mathrm{C}\right.$, selected signals)

13.06 (br. s, $1 \mathrm{H}, J=9.9 \mathrm{~Hz}, \mathrm{OH}(5)), 5.31$ (d, $J=10.3 \mathrm{~Hz}, 1 \mathrm{H}, \mathrm{CH}(1)), 3.91$

(ddd, $J=10.3,10.1,2.7 \mathrm{~Hz}, \mathrm{CH}(2)), 3.60$ (dd, J = 17.3, 2.7, $1 \mathrm{H}, \mathrm{CH}_{2}(3 \mathrm{a})$ ), 2.96

(dd, $1 \mathrm{H}, J=17.1,10.1 \mathrm{~Hz}, \mathrm{CH}(3 \mathrm{~b})), 2.33$ (s, $3 \mathrm{H}, \mathrm{CH}_{3}(6)$ )

${ }^{13} \mathrm{C}$ NMR: $\quad\left(126 \mathrm{MHz}, \mathrm{CD}_{2} \mathrm{Cl}_{2},-70{ }^{\circ} \mathrm{C}\right.$, selected signals)

$178.9(\mathrm{C}(4)), 61.3(\mathrm{C}(1)), 45.3(\mathrm{C}(2)), 38.2$ (C(3)), 19.3 (C(6)) 


\section{Reaction of Benzeneselenenyl Hexafluoroantiminate with (E)-Methyl 4-Phenyl-3-butenoate} 15g Generation of Seleniranium Salt 19 and Conversion into Adduct Me-21a [MGE-VII81]

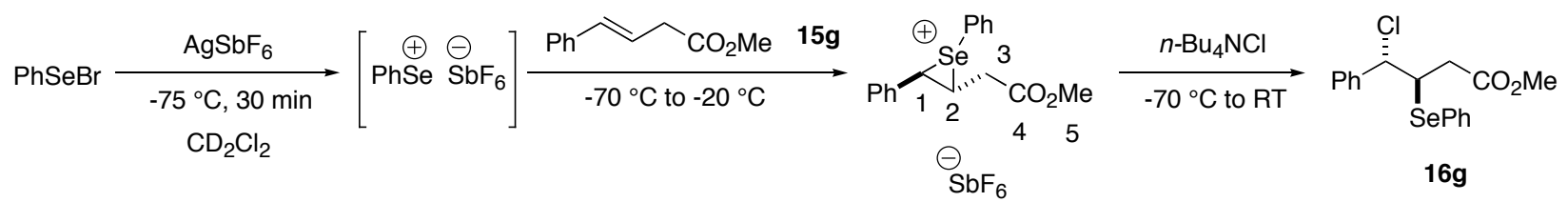

A flame-dried, $10 \mathrm{~mL}$, two-neck, round-bottom flask under argon containing a magnetic stir bar was charged with silver hexafluoroantiminate $\left(280 \mathrm{mg}, 0.816 \mathrm{mmol}, 4.8\right.$ equiv). $\mathrm{CD}_{2} \mathrm{Cl}_{2}(1.5$ $\mathrm{mL}$ ) was added via syringe and the pale-yellow solution was cooled to $-75{ }^{\circ} \mathrm{C}$ (bath temperature, acetone $\left./ \mathrm{CO}_{2}\right)$. A solution of benzeneselenenyl bromide (193 mg, $0.816 \mathrm{mmol}, 4.8$ equiv) in $\mathrm{CD}_{2} \mathrm{Cl}_{2}(0.5 \mathrm{~mL})$ was added via syringe resulting in the immediate formation of a black suspension. Whilst this mixture was stirred for $30 \mathrm{~min}$ at $-75^{\circ} \mathrm{C}$, an oven-dried NMR tube fitted with a septum cap was charged with $(E)$-methyl 4-phenyl-3-butenoate $\mathbf{1 5 g}$ (30.0 mg, $0.17 \mathrm{mmol}$, 1.0 equiv). The tube was attached to a vacuum manifold via an inlet needle and was purged 3 times with a vacuum/argon cycle and then maintained under an atmosphere of argon. The tube was immersed in the $-75^{\circ} \mathrm{C}$ cool-bath and then a $0.5 \mathrm{~mL}$ aliquot $(0.204 \mathrm{mmol}, 1.2$ equiv) of the benzeneselenenyl hexafluoroantiminate suspension added rapidly via syringe. The NMR tube was vortexed for $10 \mathrm{sec}$ resulting in immediate decolorization to a heterogeneous yellow suspension. The tube was taken to the pre-cooled $\left(-70{ }^{\circ} \mathrm{C}\right) \mathrm{NMR}$ magnet and inserted. The mixture was aged for $10 \mathrm{~min}$ at $-70{ }^{\circ} \mathrm{C}$ and then ${ }^{1} \mathrm{H}$ NMR (64 scans), ${ }^{13} \mathrm{C}$ NMR (512 scans) and ${ }^{19} \mathrm{~F}$ NMR (256 scans) spectra were recorded. The temperature was increased to $-50{ }^{\circ} \mathrm{C}$ and -20 ${ }^{\circ} \mathrm{C}$ and this process was repeated at both temperatures. After being re-cooled to $-70{ }^{\circ} \mathrm{C}$, the tube was removed from the NMR machine and a solution of $n$-tetrabutylammonium chloride (61 mg, $0.221 \mathrm{mmol}, 1.2$ equiv) added. The NMR tube was vortexed for $10 \mathrm{sec}$ and was rapidly reinserted into the magnet. The mixture was aged 20 for min at $-70{ }^{\circ} \mathrm{C}$ and then both the ${ }^{1} \mathrm{H}$ NMR (64 scans) and ${ }^{13} \mathrm{C}$ NMR (512 scans) spectra were recorded. The mixture was then warmed to $50,-20,0$ and $20^{\circ} \mathrm{C}$ (20 min at each temperature) and the ${ }^{1} \mathrm{H}$ NMR (64 scans) spectrum was recorded. Under these conditions, the data recorded in Table 8 was obtained. 
Data for 19:

${ }^{1} \mathrm{H}$ NMR: $\quad\left(500 \mathrm{MHz}, \mathrm{CD}_{2} \mathrm{Cl}_{2},-20{ }^{\circ} \mathrm{C}\right)$

7.50 (t, $J=7.4 \mathrm{~Hz}, 1 \mathrm{H}), 7.44(\mathrm{t}, J=7.4 \mathrm{~Hz}, 1 \mathrm{H}), 7.08-7.32(\mathrm{~m}, 8 \mathrm{H}), 6.60(\mathrm{~d}, J=$ $13.0 \mathrm{~Hz}, 1 \mathrm{H}, \mathrm{CH}(1)), 5.34$ (ddd, $J=12.9,5.3,3.1 \mathrm{~Hz}, 1 \mathrm{H}, \mathrm{CH}(2)), 3.83-3.86$ (m, $\left.1 \mathrm{H}, \mathrm{CH}_{2}(3 \mathrm{a})\right), 3.84\left(\mathrm{~s}, 3 \mathrm{H}, \mathrm{CH}_{3}(5)\right), 3.60\left(\mathrm{dd}, \mathrm{J}=19.6,5.3 \mathrm{~Hz}, \mathrm{CH}_{2}(3 \mathrm{~b})\right)$

(500 MHz, $\mathrm{CD}_{2} \mathrm{Cl}_{2},-50{ }^{\circ} \mathrm{C}$, selected signal)

$3.85\left(\mathrm{dd}, J=19.2,3.1 \mathrm{~Hz}, 1 \mathrm{H}, \mathrm{CH}_{2}(3 \mathrm{a})\right)$

${ }^{13} \mathrm{C} \mathrm{NMR}: \quad\left(126 \mathrm{MHz}, \mathrm{CD}_{2} \mathrm{Cl}_{2},-20{ }^{\circ} \mathrm{C}\right)$

$170.9(\mathrm{C}(4)), 135.3,134.4,133.5,130.8,129.4,124.7,122.7,90.3(\mathrm{C}(1)), 65.7$

$(\mathrm{C}(2)), 53.7(\mathrm{C}(5)), 33.4(\mathrm{C}(3))$

${ }^{19}$ F NMR: $\quad\left(376 \mathrm{MHz}, \mathrm{CD}_{2} \mathrm{Cl}_{2},-20{ }^{\circ} \mathrm{C}\right)$

-116.85 (v br), -127.56 (v br)

VT-NMR Crossover Experiment Between (E)-4-Phenyl-3-butenoic Acid 10 and (E)-4-(2Methylphenyl) 3-Butenoic Acid 23 with Benzeneselenenyl Chloride Starting with Acid 10 [MGE-VII-77]

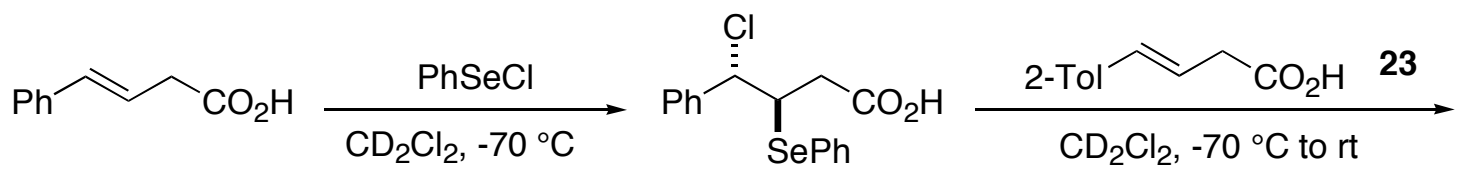

10

$16 \mathbf{a}$

An oven-dried NMR tube was cooled in a dessicator and then was charged with benzeneselenenyl chloride (17.9 $\mathrm{mg}, 0.0935 \mathrm{mmol}, 1.1$ equiv), capped with a rubber septum and then was attached to a vacuum manifold via an inlet needle. The tube was purged 3 times with a vacuum/argon cycle and then was maintained under an atmosphere of argon. $\mathrm{CD}_{2} \mathrm{Cl}_{2}(0.4 \mathrm{~mL})$ was added via syringe and the tube was vortexed for $15 \mathrm{sec}$ to afford an orange/brown solution. The tube was immersed in a $-75^{\circ} \mathrm{C}$ cold bath (bath temperature, acetone/ $\mathrm{CO}_{2}$ ) which resulted in precipitation of the majority of the benzeneselenenyl chloride. A solution of (E)-4-phenyl 3butenoic acid $10(13.8 \mathrm{mg}, 0.085 \mathrm{mmol})$ in $\mathrm{CD}_{2} \mathrm{Cl}_{2}(0.3 \mathrm{~mL})$ was added via cannula and the tube was momentarily removed from the cool-bath and re-vortexed to afford a homogeneous darkyellow solution. The tube was taken to the pre-cooled $\left(-70^{\circ} \mathrm{C}\right)$ NMR magnet and inserted. The 
${ }^{1} \mathrm{H}$ NMR was recorded to confirm the complete formation of $\mathbf{1 6 a}$. The tube was removed from the magnet, immersed in the $-75^{\circ} \mathrm{C}$ cold bath, re-attached to a vacuum manifold via an inlet needle and a solution of (E)-4-(2-methylphenyl) 3-butenoic acid 23 (15.0 $\mathrm{mg}, 0.085 \mathrm{mmol})$ in $\mathrm{CD}_{2} \mathrm{Cl}_{2}(0.3 \mathrm{~mL})$ was added via cannula. Following a further $15 \mathrm{sec}$ of vortexing, the tube was returned to the cooled $\left(-70{ }^{\circ} \mathrm{C}\right) \mathrm{NMR}$ magnet and was aged for $15 \mathrm{mins}$ before recording the ${ }^{1} \mathrm{H}$ NMR spectrum (64 scans). The temperature was then increased to $-50{ }^{\circ} \mathrm{C}$ and following $15 \mathrm{~min}$ more aging the ${ }^{1} \mathrm{H}$ NMR (64 scans) was recorded. This process was repeated at $-20{ }^{\circ} \mathrm{C}$ and $0{ }^{\circ} \mathrm{C}$ and then the tube was removed from the NMR spectrometer and was allowed to stand at room temperature for $12 \mathrm{~h}$. Then, a final ${ }^{1} \mathrm{H}$ NMR spectrum was recorded. Under these conditions, the data recorded in Table 8 was obtained.

VT-NMR Crossover Experiment Between (E)-4-Phenyl-3-Butenoic Acid 10 and (E)-4-(2Methylphenyl) 3-Butenoic Acid 23 with Benzeneselenenyl Chloride starting with Acid 23 [MGE-VII-78]

2-Tol $ح \mathrm{CO}_{2} \mathrm{H} \underset{\mathrm{CD}_{2} \mathrm{Cl}_{2},-70^{\circ} \mathrm{C}}{\mathrm{PhSeCl}}$ 2-Tol $\overbrace{\mathrm{SePh}_{2}}^{\mathrm{Cl}} \mathrm{CO}_{2} \mathrm{H} \stackrel{\mathrm{CD}_{2} \mathrm{Cl}_{2},-70^{\circ} \mathrm{C} \text { to rt }}{\stackrel{\mathrm{Ph}}{\longrightarrow} \mathrm{CO}_{2} \mathrm{H} \quad}$

23

25a

This experiment was undertaken according to the previous example except that acid 23 was added first, followed later by acid $\mathbf{1 0}$. Under these conditions, the data recorded in Table 9 was obtained. 


\section{References}

(1) Hoye, T. R.; Aspass, A. W.; Eklov, B. M.; Ryba, T. D. Org. Lett. 2005, 7, 2205-2208.

(2) Reich, H. J.; Renga, J. M.; Reich, I. L. J. Am. Chem. Soc. 1975, 97, 5434-5457.

(3) Schmid, G. H.; Garratt, D. G. Tetrahedron 1978, 34, 2869-2872.

(4) Boeckmann, R. K.; Shao, P.; Mullins, J. J. Org. Syn. Coll. Vol. 10, 696.

(5) Bradley, D. C.; Thomas, I. M. J. Chem. Soc. 1959, 3404-3411.

(6) Hoye, T. R.; Richardson, W. S. J. Org. Chem. 1989, 54, 688-693.

(7) Tiecco, M.; Testaferri, L.; Temperini, A.; Bagnoli, L.; Marini, F.; Santi, C. Synlett 2001, 1767-1771 .

(8) Fittig, R.; Obermuller, P.; Schiffer, C. Liebigs. Ann. Chem. 1892, 268, 71-72

(9) Salomon, M. F.; Pardo, S. N.; Salomon, R. G. J. Am. Chem. Soc. 1984, 106, 3797-3802.

(10) Because of problems of irreproducibility and freezing of the mixture at the higher concentrations $(0.22 \mathrm{M})$ used in all the other VT-NMR experiments this reaction was carried out a $0.11 \mathrm{M}$ concentration. Under these conditions no freezing was observed.

(11) Although the spectra of $\mathbf{1 8 a}$ could successfully be recorded at $-70{ }^{\circ} \mathrm{C}$, the signals were not sufficiently resolved to determine the coupling constants. No difference in chemical shift was observed between the spectra recorded at $-70{ }^{\circ} \mathrm{C}$ and at $-50{ }^{\circ} \mathrm{C}$. 
Denmark and Edwards

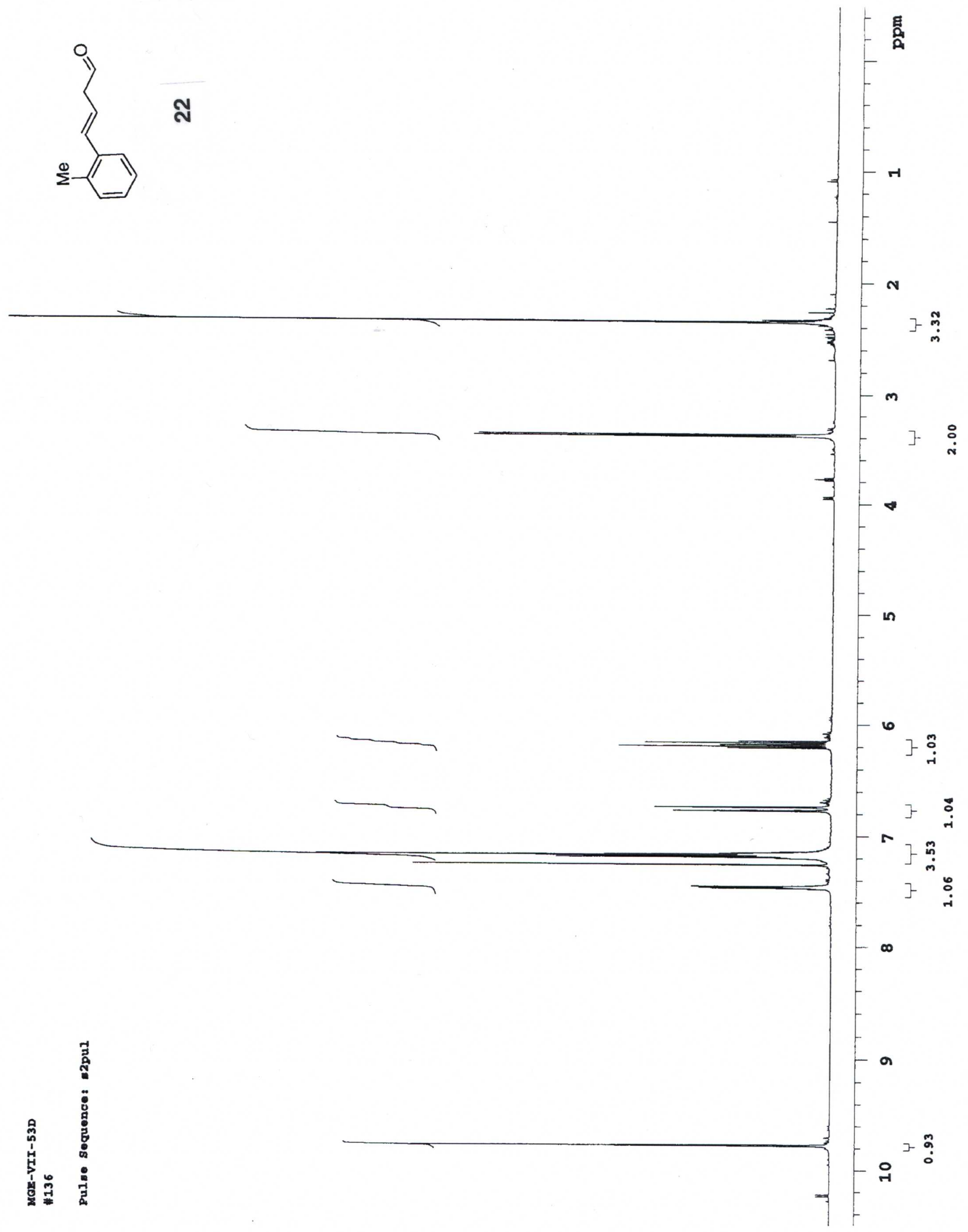




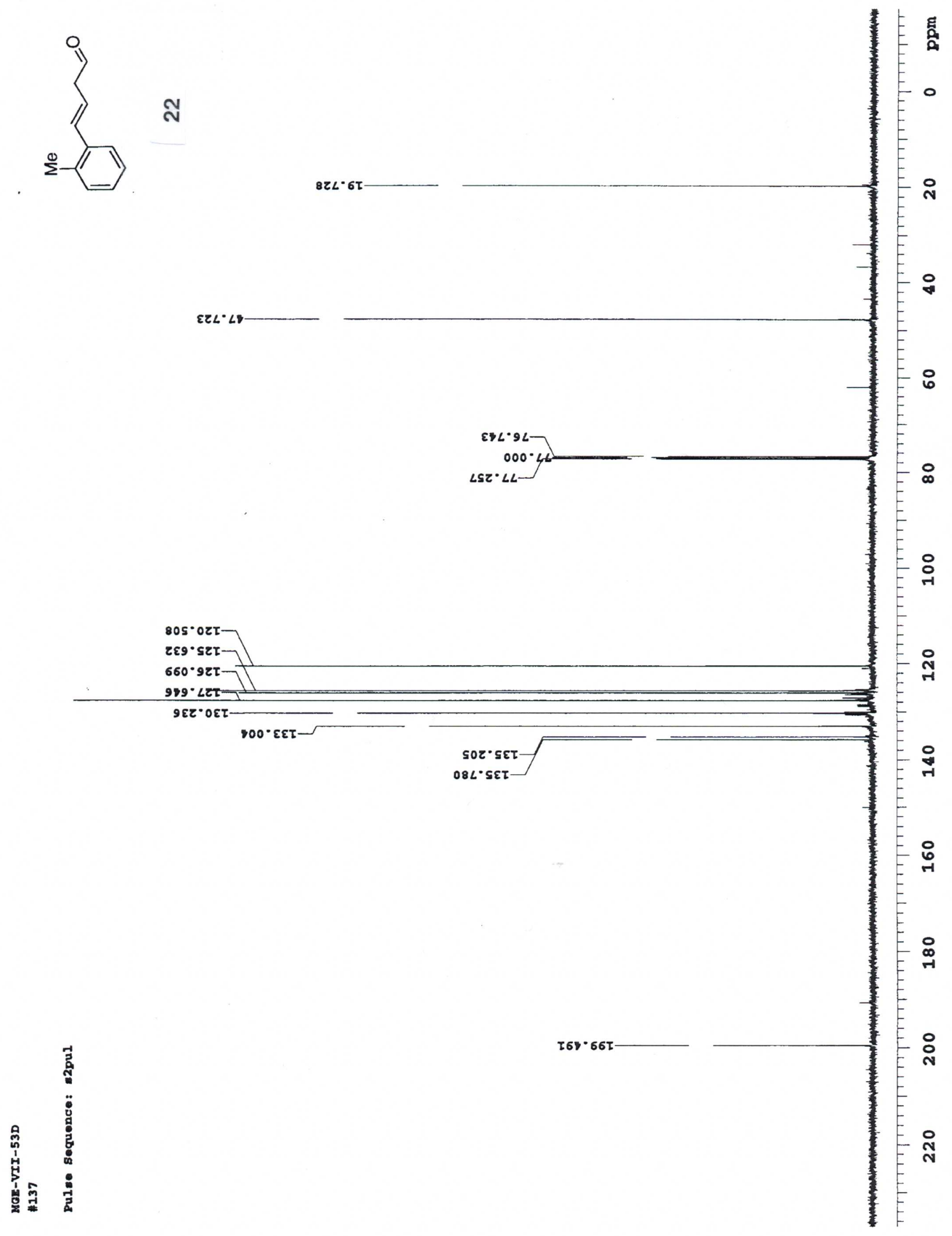

